\title{
Perspective on the Therapeutics of Anti-Snake Venom
}

\author{
Isabel Gómez-Betancur ${ }^{1}\left(\mathbb{0}\right.$, Vedanjali Gogineni ${ }^{2}{ }^{\circledR}$, Andrea Salazar-Ospina ${ }^{3}$ and \\ Francisco León $4, *$ iD \\ 1 Ophidism-Scorpionism Program, Faculty of Pharmaceutical and Food Sciences, University of Antioquia \\ UdeA, Medellín 1226, Colombia \\ 2 Analytical Department, Cambrex Pharmaceuticals, Charles City, IA 50616, USA \\ 3 Research group in Pharmacy Regency Technology, Faculty of Pharmaceutical and Food Sciences University \\ of Antioquia UdeA, Medellín 1226, Colombia \\ 4 College of Pharmacy, University of Florida, Gainesville, FL 32610, USA \\ * Correspondence: jleonoyola@cop.ufl.edu
}

Received: 11 August 2019; Accepted: 6 September 2019; Published: 9 September 2019

\begin{abstract}
Snakebite envenomation is a life-threatening disease that was recently re-included as a neglected tropical disease (NTD), affecting millions of people in tropical and subtropical areas of the world. Improvement in the therapeutic approaches to envenomation is required to palliate the morbidity and mortality effects of this NTD. The specific therapeutic treatment for this NTD uses snake antivenom immunoglobulins. Unfortunately, access to these vital drugs is limited, principally due to their cost. Different ethnic groups in the affected regions have achieved notable success in treatment for centuries using natural sources, especially plants, to mitigate the effects of snake envenomation. The ethnopharmacological approach is essential to identify the potential metabolites or derivatives needed to treat this important NTD. Here, the authors describe specific therapeutic snakebite envenomation treatments and conduct a review on different strategies to identify the potential agents that can mitigate the effects of the venoms. The study also covers an increased number of literature reports on the ability of natural sources, particularly plants, to treat snakebites, along with their mechanisms, drawbacks and future perspectives.
\end{abstract}

Keywords: Anti-venom; medicinal plants; plant constituents; snakebite treatment; snake venom

\section{Introduction}

Snakebite envenomation is a grave public health issue in many regions of the planet, particularly in Africa, Asia, Central and South America, and Oceania. Snakebite envenomation is a neglected tropical disease that kills more than 100,000 people and maims more than 400,000 people every year. Members involved in public health contemplate that the neglected tropical diseases (NTDs) that affect human lives in developing countries are generally tropical infectious diseases, such as guinea worm, leishmaniasis, dengue, onchocerciasis, Chagas disease, and leprosy. The World Health Organization (WHO), together with the support of drug manufacturers and special interest groups, initiated a coordinated effort to address several of these diseases in 2005. Subsequently, a historical report on these problems was published in 2010, and consequently a strategic plan for eradication and control emerged. Today, the WHO lists 17 NTDs on its website as targets for eradication. On 27 May 2013, the WHO World Health Assembly adopted resolution EB132.R7, urging the 194 member states to expand their programs to prevent, control, eliminate, and eradicate all the 17 NTDs [1]. Although the WHO added snakebite envenomation to its official NTD list in March 2009, it was later quietly removed along with podoconiosis and strongyloidiasis and added to a separate list of what is called "other forgotten conditions"; a list that is not included in any of the WHO plans to eradicate NTDs, and is not even mentioned in their reports for 2010 and 2013 [2]. Fortunately, snakebites were re-included in 
category A of neglected tropical diseases (NTDs) in June 2017 and are recognized by the WHO [3]. This recognition is important and necessary to change the reality of this neglected tropical disease that continues to inflict a high cost of suffering and chronic disability in many of the poorest and most marginalized communities in the world.

It has been difficult to identify the exact incidence due to inadequate health statistics and the fact that some patients do not pursue medical care. In 2008, global annual incidence was estimated to be between 1.8 to 5.4 million bites [4]. According to the WHO, recent estimates suggested around 80-140,000 deaths/year, 400,000 amputations, and other long-lasting incapacities and disabilities caused due to snakebite envenomation [5]. Snakes with major clinical importance belong to the families Elapidae (African and Asian cobras, Asian kraits, African mambas, American coral snakes, Australian and New Guinean venomous snakes, and sea snakes) and Viperidae (Old World vipers, American rattlesnakes and pit vipers, and Asian pit vipers). An extended list is found in the WHO guidelines for the production, control, and regulation of snakebite antivenom immunoglobulins [6].

Envenomation is the result of the injection of a highly specialized toxic secretion, called venom, by a venomous snake into a human, usually in accidental situations [7]. Venom is injected through the snake's fangs, which are teeth connected via a duct to a venom gland. The composition of snake venom shows high complexity and diversity, resulting in variable biochemical and toxicological profiles that determine a wide range of clinical manifestations. Snake venoms contain enzymes, including phospholipases A2, metalloproteases, serine proteases, L-amino acid oxidases, nucleotidases, and hyaluronidases [7,8]. The pathophysiology of snake envenomation involves a complex series of events that depend on the combined actions of these venom components. Toxins of the Bothrops snake venom mainly affect the muscle tissues along with blood clotting. Symptoms include pain, swelling, and bleeding (at the site of the bite and the mucous membranes), and in cases where complications can occur, blisters, gangrene, shock, and acute renal failure are observed. In other types of envenomation, such as from the genus Crotalus venom, the nervous system (neurotoxic) and muscles are affected along with clotting, and in severe cases acute renal failure and death may occur [9]. However, the presence and concentration of snake venom can vary depending on the geographic distribution, age, sex, diet, size, and season, among others [10]. Local tissue damage effects, such as hemorrhage, myonecrosis, and edema, are among the most dramatic effects of envenomation.

Ophidic accidents are a serious problem in public health due to the resulting high morbidity and mortality rates. The only specific treatment available is antivenom. Therefore, the search for complementary alternatives for snakebite treatment is very important and necessary. In order to develop alternatives to current therapies, researchers have been looking for bioactive compounds isolated from plant extracts with different properties such as analgesic, anti-myotoxic, anti-hemorrhagic, and anti-inflammatory effects for many years. In recent years, studies have been published that have provided pharmacological evidence regarding the benefits of various extracts and compounds isolated from different plant species against the local and systemic effects induced by a wide range of snake venoms, including lethality [11-13]. In this context, this review has aimed to provide an up-to-date description of the bioactive compounds that are isolated from various natural sources and tested as potential anti-ophidic agents and to unify the information and relevant data to help understand the diversity of these bioactive compounds, their actions on snake venom, and the prospects for future applications against venomous toxins. Additionally, a brief discussion on the open opportunities of using snake venoms as therapeutic agents is included.

\section{Methodology}

An extensive review of the literature was conducted, which came from different scientific sources, such as PubMed (https://www.ncbi.nlm.nih.gov/pubmed), Science Direct (http://www.sciencedirect. com/), Scopus (https://www.scopus.com/), Web of Science (http://www.webofknowledge.com/), Scientific Electronic Library Online (SciELO) (http://www.scielo.org/), Scifinder, and Google Scholar (https://scholar.google.com). The study databases included original articles published in peer-reviewed 
journals, as well as books, theses, dissertations, patents, and other reports covering information related to plants used in the treatment of snakebite envenomation (ethnopharmacological studies, original articles, or comments). The data and summaries of the complete articles were considered, selecting information in English, Portuguese, and Spanish. Publications with ethnobotanical studies, bioactive substances, or bio-guided pharmacological studies were analyzed in the search for therapeutic alternatives for the treatment of snakebites.

\section{Current Information in the Design of New Antivenoms}

Currently, the only accepted treatment for snakebite envenomation involves intravenous administration of conventional antivenoms comprising antibodies or antibody fragments derived from the plasma of large mammals (generally horses, but also sheep, goats, or rabbits) that have been previously immunized with non-lethal venomous doses $[14,15]$. Hyperimmunized animals produce antibodies against the venom proteins and serum is extracted from their blood for the treatment of envenomation $[6,16]$. Conventional serum therapy aims to bind and neutralize the snake venom proteins [17]. It is a fact that the antivenom allows the body to try to reverse the damage caused by the venom. However, it is known that such therapy can cause problems related to different antivenom characteristics, such as:

- Immediate hypersensitivity reaction to the alien immunoglobulins, including anaphylactic and pyrogenic reactions such as chills, rigor, headache, and tachycardia. Delayed antivenom reactions or serum sickness is observed after 8 to 12 days of treatment; these are characterized by cutaneous eruptions, fever, and allergies, among other effects [18];

- Limited efficacy of antivenom therapy to protect the affected organ/s against immediate local tissue damage and low stability;

- Ineffectiveness of the antivenom due to significant geographic variation in the composition of the venom;

- Antigenic reactivity due to the taxonomic diversity of the snakes;

- Improper use of the antivenom due to incorrect medical management, which contributes to a high incidence of adverse reactions, a low toxin neutralizing potency, or both.

Manufacture of antidotes from hyperimmunized animals is another problem that affects the access and use of antidotes in rural populations, mainly in developing countries. There is a deficiency in the availability of antidotes and lack of training in the clinical staff, worsening the consequences of the ophidian accidents and leading to increased incidence of death. These factors, together with distribution problems, unattractive profit margins, and high costs in developing and developed countries, reduce the viability and the interest of the pharmaceutical industries in the manufacture of antivenom serums [19]. There has been a decline in the number of producers in both private and public sectors. Chippaux provides three reasons for this dramatic reduction:

- The instability in the antivenom market;

- Little financial incentive for pharmacists and health centers to sell antivenom due to the low profit margins;

- Lack of comprehensive data on how many doses of antivenom are required and where they should be distributed [20].

Moreover, we must consider the supplementary therapeutic actions that a snakebite patient may require for effective treatment, such as the use of extra drugs, wound care services, reconstructive surgery, and rehabilitation therapy, all of which increase the total cost associated with this NTD.

Recombinant antivenoms with oligoclonal mixes of human monoclonal antibodies are the next-generation therapy for improved treatment of snakebites. A cocktail of human antibodies is needed for efficacious and high-quality biosynthetic oligoclonal antibodies (BOA) for the treatment of snakebites. BOA cocktails include all or most of the significant toxins that are needed for the 
pathophysiology of a snakebite. These toxins range from 20 to in excess of 40 neutralizing antibodies together with carefully selected human recombinant antibodies for a specific number of snake venoms. Depending on the specificity and number of monoclonal antibodies, BOAs can be monovalent or polyvalent. The general idea of the combination of small molecule inhibitors together with a BOA cocktail is that it could lead to improved neutralization of toxins in distal tissue by improving the pharmacokinetics [21]. With the increased bioinformatic tools and the availability of protein structural databases, several metabolites isolated from different sources, such as plants, bacteria, fungi, and other synthetic processes, have been evaluated for their ability to inhibit enzymes found in snake venoms [22]. Small molecule enzyme inhibitors could provide several potential advantages; for example, serving as adjuvants and reducing the effects of intoxication while the patient is being treated in a health care center, which would increase the recovery time, thereby improving the treatment window. Furthermore, since many of these small molecule inhibitors have been evaluated for their toxicity in human receptors, they have already proven to be safe enough to be used in the treatment of snakebite envenomation.

Another approach for the development of snake antivenoms includes independent venom immunization techniques. There are four different strategies involved in this approach. The first strategy includes the injection of chemically synthesized epitopes of toxins, where bioinformatic software is used for the prediction of epitopes or epitope mapping studies. The second strategy involves not only the toxin epitopes but also the use of full-length recombinant or synthetic toxins as immunogens. In the third strategy, molecules with non-identical amino acid sequences that mimic the structure of the toxin epitopes, called mimotopes, are used. The final strategy involves the use of DNA, avoiding recombinant expression or chemical synthesis [14,23].

\section{Current Drugs for the Treatment of Snakebites in the United States}

The country most-affected by snakebites is India, with 46,000 deaths/year and around 4.1 cases of snakebite per 100,000 inhabitants [24]. According to the Centers for Disease Control and Prevention (CDC), an estimated 7000 to 8000 snakebites occur annually in the United States (CDC 2018). The 2017 annual report of the American Association of Poison Control Centers (AAPCC) showed around 7000 snakebites. Copperheads (2035), Crotalids, (1028), and rattlesnakes (753) were reported as the predominant species involved in envenomation; however, death is a rare outcome and only 5-10 deaths were reported [25]. Commercial antivenoms comprise the polyvalent and monovalent immunoglobulins, which are employed for a group of snake species or a single snake species, respectively [26]. In the United States, there are three Food and Drug Administration (FDA) approved drugs to treat snakebites:

- Antivenin ${ }^{\circledR}$ Wyeth (equine), approved to treat envenomation from the American coral (Micrurus fulvius) [27];

- $\quad$ Crofab ${ }^{\circledR}$ Crotalidae polyvalent immune FAB (ovine), approved in 2000 for snakebite envenomation from multiple species, including Crotalus atrox (western diamondback rattlesnake), Crotalus adamanteus (eastern diamondback rattlesnake), Crotalus scutulatus (Mojave rattlesnake), Agkistrodon contortrix (copperhead), and Agkistrodon piscivorus (cottonmouth or water moccasin) [28];

- $\quad$ Anavip ${ }^{\circledR}$ Crotalidae Immune $F\left(a^{\prime}\right) 2$ (equine), approved in 2015 to treat envenomation from the rattlesnakes Crotalus durissus and Bothrops asper [29].

Current antibody production faces challenges during the immunization of the animal (equine or ovine), leading to the production of a huge number of antibodies that are not related to the snake venom. Around $70 \%$ of the immunoglobulins obtained do not act directly against venom toxins [26]. Despite the abovementioned facts, this is the only FDA approved therapy to treat snake venom.

In many countries, the production and manufacture of antivenoms are mainly managed by governmental agencies or laboratories that are directly linked to the local national health authorities [30]. For example, since 1930 the Commonwealth Serum Laboratories (CSL) in the Seqirus division have 
produced mono- and polyvalent snake antivenoms for the most dangerous snakes in Australia, including black snake (Pseudechis genus), brown snake (Pseudonaja genus), death adder (Acanthophis genus), sea snake (Hydrophis spiralis), taipan (Oxyuranus genus), and tiger snake (Notechis scutatus). CSL provides the antivenoms for Australia's universal health care system, which distributes these antivenoms within its territory. Despite the high number of dangerous snakes in Australia, the average number of deaths from snake envenomation is only 4 per year [31].

\section{Folkloric Medicine in the Treatment of Snake Envenomation}

In traditional medicine, herbal preparations were mainly used as decoctions, and this dosage form is still used in Asian, African, and Central and South American countries. The disadvantages of the herbal decoction include drawbacks in terms of use, unstable composition, and stability problems. Difficulties of decoctions could be overcome using plant extracts, which contain hundreds of active ingredients that can be potentially useful in the development of therapeutic agents. In addition, there are several other conventional and current techniques used to extract compounds from their natural sources (Figure 1). The identification and isolation of phytochemical groups from natural sources are, therefore, crucial in the drug discovery paradigm. It has been estimated that there are at least 15 major chemical groups in all the natural sources (flavonoids, alkaloids, glucosides, glycosides, volatile oils, resins, phytochromes, organic acids, amino acids, tannins, proteins, enzymes, trace elements, polysaccharides, and mineral salts among others). For example, flavones include more than 9000 known structures [32]. Alkaloids are a major class of compounds; thousands of alkaloids have been isolated. From which hundreds are being used clinically. Secondary metabolites from natural sources with hemostatic, antidiarrheal, antiulcer, antimicrobial, antiviral, wound healing, antitumor, anti-inflammatory, and anti-oxidant properties can be a foundation for therapeutic antivenom drugs [32].

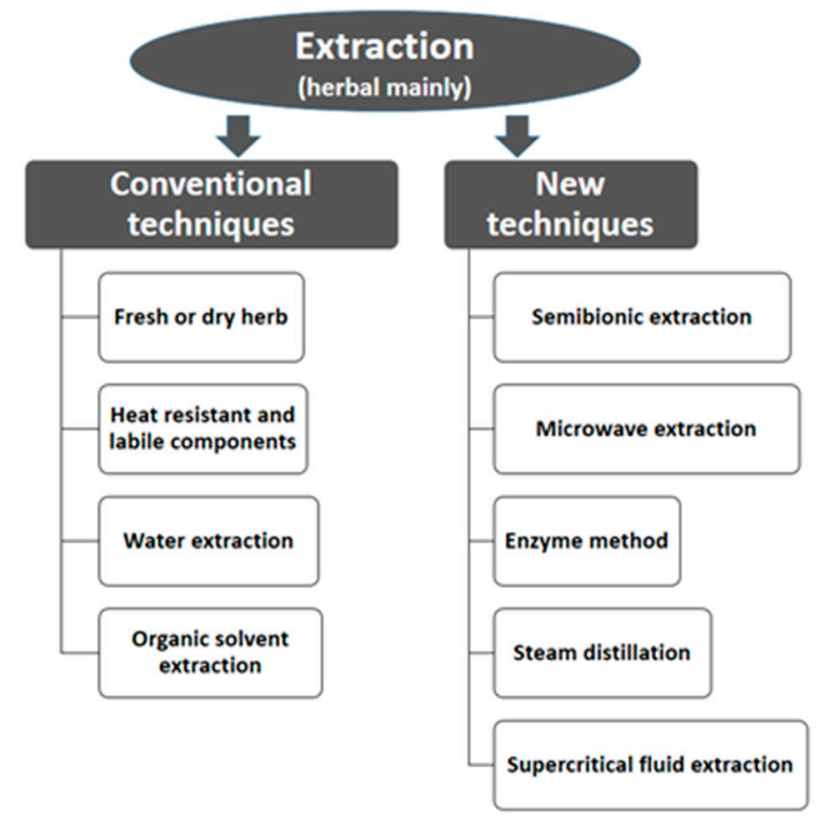

Figure 1. Current extraction techniques for herbal medicines.

The process of developing typical drugs or even a phytotherapeutic from herbal sources is a long process that includes at least four stages:

- The isolation or derivatization of bioactive substances from natural sources;

- The evaluation of safety and efficacy using pharmacological methods;

- Evaluation of safety and efficacy by conventional pharmacological methods (pharmacodynamics, toxicology, and pharmacokinetics); 
- Regulatory approval of the therapeutic agent to be used in the market and in post-marketing supervision, as well as pharmacovigilance.

Studies showed that secondary metabolites isolated mainly from plants can clearly affect human homeostasis [33] by becoming the basis for production of many phytotherapeutics [34,35] and in the design of new medicines [36,37]. Currently, more than $55 \%$ of medicinal compounds are derived from natural products. Furthermore, $60 \%$ of the current anticancer compounds and $75 \%$ of the medicines used in the treatment of infectious diseases are either natural products or products derived from or inspired by natural sources, or use their pharmacophore as a model [38].

Plant extracts, fractions, and isolates have demonstrated the inhibitory activity of snake venoms, including their purified toxins. These inhibitors not only reduce the local tissue damage but also delay the easy diffusion of systemic toxins, and therefore, increase the survival time of the patient. The continuity of the studies on the mechanism of action and the safety of these molecules will reveal their potential use in the development of new therapies for snakebites. Several lists of medicinal plant species with activity against snake venom have been published, adding more than a thousand species that are used in folk medicine around the world [12,39].

Many indigenous and farmer communities make use of the resources available to them (usually plants) as an alternative to antivenom therapy, using extracts, baths, or infusions of medicinal plants in an effort to treat or minimize venom effects, such as hemorrhage and edema [40]. Clearly, ethnobotanical studies have been able to identify medicinal plants and active compounds that inhibit the action of snake venom. This knowledge has been used for the development of alternative therapies to treat the effects of snakebite envenomation. Although it is known that many plants are active against various effects of snakebites, few studies have been conducted to investigate the validity of these results under controlled conditions in both in vitro and in vivo models in order to demonstrate if there is any protective effect using simple molecules or prepared mixtures simulating traditional formulas [40]. For instance, ethnobotanical studies on the use of Costa Rican tropical plants for the treatment of snakebites have shown interesting results, identifying to a significant number of plants from different families that could potentially inhibit the toxic effects of $B$. asper venom. In fact, the organic and aqueous extracts of several plants have shown total inhibition of the hemorrhagic effects in rodent models after intradermal injections of the venom or a mixture of venom-extracts [41]. The anti-hemorrhagic activity can be attributed to the presence of active principles in some plants, such as 4-nerolidylcatechol and edunol [42-45], as well as flavonoids, which can chelate the zinc atoms involved in the catalytic activity of the venom's hemorrhagic metalloproteinases, thereby neutralizing the hemorrhagic activity [41]. Amui and collaborators provided an innovative solution to systematize the information on medicinal plants with antivenom properties. They created a large public database that allows fast and reliable searches for information. The plant antivenom database has three types of information: medicinal plants with anti-venom properties, amino acid sequences of venom toxins, and enzymes of this theme. This computational tool displays relationships between data through different search schemes, providing a helpful resource for researchers in this field [46].

It is known that medicinal plants used against snakebites are found throughout the world, especially in tropical or subtropical regions of the Asian, American, and African continents. The need for alternative or complementary therapies to treat envenomation from snakebites is triggered due to the biodiversity related factors of the flora of these regions, as well as the difficulties in accessing adequate health services. According to Table 1, numerous studies have published several lists of medicinal plant species with activity against snake venom, adding more than 700 species used in folk medicine around the world $[11,13,39]$. These studies showed many ethnopharmacological investigations, the results of which demonstrated proven activities of medicinal plants used for the treatment of snakebites. A summary of some of these studies is shown in Table 1. 
Table 1. Research and ethnopharmacological studies from different countries for the treatment of snake envenomation

\begin{tabular}{|c|c|c|c|}
\hline Country & Plant & Description of the Study & Reference \\
\hline India & Morus alba (Moraceae) & $\begin{array}{c}\text { Extracts from Morus alba (Moraceae) are active against Daboia russelli venom, inhibiting the caseinolytic, hyaluronolytic, } \\
\text { edematogenic, hemorrhagic, and procoagulant activities. }\end{array}$ & [47] \\
\hline Nigeria & Mucuna pruriens (Fabaceae) & $\begin{array}{l}\text { Seed extract of Mucuna pruriens (Fabaceae) used in Nigerian communities offer significant protection to cardiac muscle tissue } \\
\text { and blood vessels, and even protects against the lethality produced by venoms from Naja kaouthia, Naja nivea, and } \\
\text { Calloselasma rhodostoma. This protection can be explained from the presence of a Kunitz-type trypsin inhibitor. }\end{array}$ & {$[48-50]$} \\
\hline Yemen & Hibiscus aethiopicus (Malvaceae) & $\begin{array}{l}\text { Aqueous crude extracts from Hibiscus aethiopicus (Malvaceae) possess significant anti-hemorrhagic and cytoprotective } \\
\text { activities against Echis ocellatus and Naja n. nigricollis venoms }\end{array}$ & [51] \\
\hline India & Vitis vinifera (Vitaceae) & $\begin{array}{l}\text { Administration of the methanolic extracts from Vitis vinifera (Vitaceae) resulted in the reduction of local symptoms produced } \\
\text { by D. russelli venom due to the inhibition of the proteolytic and hyaluronidase activities reducing edema, myonecrosis, and } \\
\text { hemorrhaging. }\end{array}$ & [52] \\
\hline Brazil & Dipteryx alata (Fabaceae) & $\begin{array}{l}\text { Extracts and fractions from Dipteryx alata (Fabaceae) partially neutralized Bothrops jararacussu and Crotalus durissus terrificus } \\
\text { venom activities. Hydroalcoholic bark extract from D. alata is active against B. jararacussu venom. }\end{array}$ & {$[53,54]$} \\
\hline Brazil & Marsypianthes chamaedrys (Lamiaceae) & $\begin{array}{l}\text { Infusions and crushed leaves from Marsypianthes chamaedrys (Lamiaceae) showed a similar activity produced by antivenom } \\
\text { serum against clotting and inflammatory effects of the Bothrops atrox venom }\end{array}$ & [55] \\
\hline Brazil & Hypericum brasiliense (Guttiferae) & $\begin{array}{c}\text { Hypericum brasiliense (Guttiferae) reduces the lethality produced by Bothrops jararaca by inhibiting the edematous and } \\
\text { proteolytic activities of the venom. }\end{array}$ & [56] \\
\hline India & $\begin{array}{l}\text { Luffa egyptiaca (Cucurbitaceae) and Nicotiana } \\
\text { rustica (Solanaceae) }\end{array}$ & $\begin{array}{c}\text { Ethyl acetate fractions of Luffa egyptiaca (Cucurbitaceae) and Nicotiana rustica (Solanaceae) extracts completely inhibited the } \\
\text { protease activity of Naja nigricollis venom. }\end{array}$ & [57] \\
\hline India & Mangifera indica (Anacardiaceae) & $\begin{array}{l}\text { Aqueous extracts from the stem bark of Mangifera indica (Anacardiaceae) inhibited the protease, hyaluronidase, hemorrhagic, } \\
\text { fibrinogenolytic, hemolytic, procoagulant, edema, ATPase, and alkaline phosphatase activities produced by D. russelli venom }\end{array}$ & [58] \\
\hline Argentina & Nectandra angustifolia (Lauraceae) & $\begin{array}{l}\text { Ethanolic extracts and essential oils from Nectandra angustifolia (Lauraceae) leaves inhibited the hemolytic and coagulant } \\
\text { effects produced by Bothrops neuwiedi venom }\end{array}$ & [59] \\
\hline Pakistan & Fagonia cretica (Zygophyllaceae) & $\begin{array}{l}\text { Methanolic extract from leaves and twigs of Fagonia cretica (Zygophyllaceae) is capable of inhibiting hemorrhage induced by } \\
\text { Naja naja karachiensis venom }\end{array}$ & {$[60]$} \\
\hline Brazil & Sapindus saponaria (Sapindaceae) & $\begin{array}{l}\text { Fractions of the hydro alcoholic extracts from the callus of Sapindus saponaria (Sapindaceae) partially inhibited the lethality, } \\
\text { phospholipase, clotting, edema, hemorrhagic, and myotoxic activities produced by Bothrops jararacussu, Bothrops moojeni, } \\
\text { Bothrops alternates, and Crotalus durissus terrificus venoms along with isolated myotoxins and phospholipase A2 ( } \text { PLA }_{2} \text { ) }\end{array}$ & [61] \\
\hline Brazil & $\begin{array}{l}\text { Mouriri pusa (Melastomataceae), Byrsonima } \\
\text { crassa (Malpighiaceae), and Davilla elliptica } \\
\text { (Dilleniaceae) }\end{array}$ & $\begin{array}{l}\text { Methanolic extracts from Mouriri pusa (Melastomataceae), Byrsonima crassa (Malpighiaceae), and Davilla elliptica } \\
\text { (Dilleniaceae) blocked local hemorrhages produced by Bothrops jararaca venom. }\end{array}$ & [62] \\
\hline India & Anacardium occidentale & $\begin{array}{l}\text { The efficacy of Anacardium occidentale extract against pharmacological actions induced by Vipera russelli venom was observed } \\
\text { from the neutralization of phospholipases, proteases, and hyaluronidases, as well as edema, hemorrhage, lethality, and } \\
\text { myonecrosis effects }\end{array}$ & [63] \\
\hline India & Tamarindus indica (Fabaceae) & $\begin{array}{c}\left.\text { Tamarindus indica (Fabaceae) inhibited hyaluronidase, Phospholipase A2 ( } \mathrm{PLA}_{2}\right) \text {, L-amino oxidase (LAAO), and } \\
5^{\prime} \text {-nucleotidase. Exhibited fibrinogenolytic, edema-inducing, hemorrhagic, indirect hemolytic, coagulant, and myotoxic } \\
\text { properties, and protected against venom-toxicity }\end{array}$ & [64] \\
\hline Brazil & 83 plant species, from 34 families & Inhibition of Phospholipase A2 ( $\left.\mathrm{PLA}_{2}\right)$, anti edema, anti lethality, anti clotting, myotoxicity, and antihaemorrhagic activity & [65] \\
\hline Brazil & Mandevilla velutina and Eclipta prostata & Inhibition of creatine kinase release and myotoxic activity & [66] \\
\hline
\end{tabular}


Table 1. Cont

\begin{tabular}{|c|c|c|c|}
\hline Country & Plant & Description of the Study & Reference \\
\hline Worldwide & $\begin{array}{l}\text { Schumanniophyton magnificum, Aristolochia } \\
\text { radix, Diospyros kaki, Alocasia cucullata, } \\
\text { Picrasma quassioides, Eclipta prostrata, } \\
\text { Curcuma sp., Soja hispida, Diodia scandens, } \\
\text { Andrographis paniculata }\end{array}$ & $\begin{array}{l}\text { Inhibition of Phospholipase } \mathrm{A} 2\left(\mathrm{PLA}_{2}\right) \text { or other enzymes (Adenosine triphosphatese), and life-prolongation effect post black } \\
\text { mamba venom treatment. }\end{array}$ & [67] \\
\hline Colombia & 77 plant species & $\begin{array}{l}\text { Three relevant studies: First study was an inventory with } 77 \text { species of plants belonging to } 41 \text { families used by Colombian healers } \\
\text { along with the methods of preparation, administration, and dosage; second study was a list of } 74 \text { ethanolic plant extracts used by } \\
\text { folk medicinethat were active against lethal effects produced by Bothrops atrox venom; third study showed } 31 \text { extracts with } \\
\text { moderate or high neutralizing abilities against the hemorrhagic effect of B. atrox venom }\end{array}$ & [68] \\
\hline Brazil & Numerous plant species & $\begin{array}{l}\text { Review discussing Brazilian plant species displaying neutralizing properties against snake envenomation from an } \\
\text { ethnopharmacological perspective }\end{array}$ & [69] \\
\hline Costa Rica & 40 plant species & 40 plant species belonging to at least 30 families. Neutralization activity of Costa Rican plants towards B. asper venom and toxins & [70] \\
\hline India & 34 plant species & $\begin{array}{l}\text { A list of } 34 \text { plant species belonging to the Zingiberaceae family traditionally used in Northeast India, where one species presented } \\
\text { antivenom activity and five other species have been scientifically validated to be anti-inflammatory }\end{array}$ & [71] \\
\hline $\begin{array}{l}\text { Nepal, } \\
\text { China, South } \\
\text { Africa, } \\
\text { Nicaragua, } \\
\text { and Brazil }\end{array}$ & 310 plant genera from 171 families & Enzyme inhibition activity & [72] \\
\hline India & 69 plant species & $\begin{array}{l}69 \text { plant species belonging to } 29 \text { genera and } 17 \text { compounds with antiophidian activity or relative properties against venoms from } \\
34 \text { snake species }\end{array}$ & [73] \\
\hline $\begin{array}{l}\text { Nigeria and } \\
\text { Ghana }\end{array}$ & $\begin{array}{l}\text { Schumanniophyton magnificum, Strophanthus } \\
\text { gratus, Strophanthus hispidus, Mucuna pruriens }\end{array}$ & Aqueous extracts showed effects on the blood clotting against Echis carinatus envenomation & [74] \\
\hline $\begin{array}{c}\text { Mali, DR } \\
\text { Congo, } \\
\text { South Africa }\end{array}$ & 94 species of 84 genera & $\begin{array}{l}\text { List of plants used traditionally in sub-Saharan Africa. Hyaluronidase, phospholipase A2, and protease inhibitory activity against } \\
\text { effects produced by Bitis arietans, and Naja nigricollis venom }\end{array}$ & [75] \\
\hline
\end{tabular}




\section{Mechanisms of Action of Antivenoms Derived from Herbs}

The antigen-antibody reaction is the basic mechanism for the neutralization of snake venom by antivenoms. For small molecules, there are some hypotheses proposed on how those small compounds neutralize the toxic components of the venom. Several literature reports indicate the mechanism of inactivation; for example, through precipitation or inactivation of proteins [76], inactivation or enzyme inhibition [77], chelation [41], adjuvant action [78], antioxidant activity [79], or a combination of these activities. Among these, protein precipitation and enzyme inhibition are the most accepted [40].

\subsection{Protein Precipitation}

Several secondary metabolites with protein binding properties against snake envenomation include flavonoids, polyphenols, saponins, tannins, terpenoids, xanthenes, quinonoids, steroids, and alkaloids. These bind to the toxic proteins of the venom, thereby inactivating them. They could also competitively block target receptors [80]. Flavonoids have been reported for their ability to interact with the components of the snake venom and inhibit their activity; for example, pinostrobin, an isolated flavanone from the leaves of Renealmia alpinia, has been reported for its anti-hemorrhagic and antimyotoxic activities, along with its ability to neutralize the in vitro activities against the venom of B. asper [81].

\subsection{Enzyme Inactivation/Inhibition}

Snake venom phospholipase A2 ( $\left.\mathrm{PLA}_{2}\right)$, metalloproteases, and hyaluronidases are the key enzymes involved in snake venom toxicity [82]. Thus, inactivation of these enzymes is generally considered the fundamental step in the management of snakebites. Polyphenolic compounds such as tannins are specialized metabolites found in many plant species and have been shown to interact with the enzymes of the snake venom by non-specific binding proteins [83]. Several studies have concluded that the effect of polyphenolic compounds in snake venoms is due to the interaction between the enzymes of the venom and the hydroxyl groups (through hydrogen bonds) in these types of metabolites, resulting in the formation of a stable complex [84]. It has been reported that the high-resolution crystal structures of the two PLA 2 complexes isolated from the venom of Daboia russelli pulchella and made with anisic acid and atropine [85] indicated that the networks of hydrophobic interactions and hydrogen bonds stabilized the positions at the substrate by binding to the enzyme. Significant interactions with His48 and Asp49 were observed in both complexes [86].

\subsection{Chelation Activity}

Plant extracts have compounds that bind to divalent metal ions, which are necessary for some enzymatic activities. Since proper coordination of metal ions is a prerequisite for the hydrolytic activities of $\mathrm{PLA}_{2}$ and metalloproteases, any metabolite that can weaken the enzyme-metal ion interaction will result in inactivation of the hydrolytic activity [87].

\subsection{Adjuvant Action}

The 2-hydroxy-4-methoxybenzoic acid isolated from the root extract of Hemidesmus indicus neutralized the pathophysiological changes induced by snake venoms through adjuvant effects and potentiation of the antiserum. Increased production of antibodies in hyperimmunized rabbits was evidenced from the increased neutralization of venom (lethal and hemorrhagic activity). This compound also acted as an adjuvant by triggering the retention of small venom antigen particles and aiding in the formation of antibodies [78].

\subsection{Antioxidant Activity}

Compounds such as vitamins A, C and E, flavonoids, terpenoids, tannins, polyphenols, and some minerals (i.e., selenium) from plants have the ability to neutralize free radicals; hence, they are valuable 
natural antioxidants that can scavenge and remove oxygen free radicals, stabilize cell membranes, and act as immunomodulators [88]. These classes of compounds are known to be powerful antioxidants both in hydrophilic and lipophilic environments. They can prevent, stop, or reduce oxidative damage due to $\mathrm{PLA}_{2}$ activity by selectively binding to the active sites or modifying the conserved residues that are critical for the $\mathrm{PLA}_{2}$ catalysis [83].

\section{Natural Products in the Development of Antivenom Agents}

The term "natural products" spans an extremely large and diverse range of chemical compounds derived and isolated from biological sources such as plants, minerals, and organic matter. Interest in natural products that have been used for over a thousand years is continuing based on the experience of randomized trials and animal observations. In ancient times, people acquired knowledge on plant use to treat diseases. For example, Chinese herbal medicine (CHM) and Indian herbal medicine (Ayurvedic) were highly developed in antiquity. China, Japan, Korea, and India still influence modern healthcare [32]. In recent years, natural products have experienced a resurgence in drug discovery programs, mainly due to their superior chemical diversity over synthetic compound libraries and their drug-like properties. There are several widely used drugs derived from natural sources, which are available in the form of food supplements, nutraceuticals, and complementary and alternative medicines. In fact, some widely used drugs used to treat certain life-threatening diseases are derived from natural sources, such as paclitaxel and artemisinin, which are used as anticancer and antimalarial agents, respectively [38].

As already discussed in Section 11, people rely heavily on other therapeutic alternatives from traditional healers with knowledge based on ancient culture, ethnic practices, and herbal antidotes because of inadequate facilities and difficulties in timely medical care, especially in rural areas. The plant kingdom provides an inexhaustible source of various herbal compounds with pharmacological potential. A large number of medicinal plants are widely used by traditional healers in the form of baths, pastes, decoctions, powders, plasters, and pills for the treatment of snakebite envenomation [89,90]. It is a known fact that secondary metabolites isolated from different sources such as plants, fungi, and bacteria are natural, have no potential side effects, are stable for a long time, can be easily stored, and some can neutralize a wide range of snake enzymes, such as phospholipase A2 (PLA 2$)$, hyaluronidase, protease, L-amino acid oxidase, and 5' nucleotidase, among others. Table 2 summarizes a list of bioactive compounds that have been studied, tested, and reported for the inhibition of one or more enzyme components of different venoms, both in in vitro and in vivo models.

The isolated small molecules with antivenom activity were categorized based on their chemical structures. Phenolic compounds are important components of plants and include hydroxybenzoic acids, coumarins, cinnamic acids, and polyphenolic compounds, among others. These essential plant constituents display antioxidant properties by trapping the reactive oxygenated species [91] and exhibit interaction with hydrolases, oxidoreductases, and isomerases [92]. Additionally, several phenolic compounds exhibit phospholipase A2 inhibition against numerous snake venoms [93-95]. There are a number of mechanisms through which phenolic compounds act as anti-snake venoms. These include the elimination of free radicals, hydrogen donation, singlet oxygen cooling, metal ion chelation, or as substrates during attack by superoxides. Another approach for the potent neutralization of snake venom by phenolic compounds could be due to the blocking of one or more enzymatic active sites in the venom toxins or the receptors that are structurally susceptible to chemical attack [93]. The aristolochic acid I (8-methoxy-6-nitro-phenanthro(3,4-d)1,3-dioxole 5-carboxylic acid) is an alkaloid present in Aristolochia species. The aristolochic acid I isolated from Aristolochia radix and Aristolochia odoratissima [96] inhibits enzymatic and pharmacological activities of a basic PLA 2 from $V$. russelli venom [97]. In molecular coupling studies performed with aristolochic acid I and PLA 2 isolated from $V$. russelli venom, [98] the most interesting interactions between these two substances are provided by their OH groups, which form two hydrogen bonds with His48 and Asp49. Moreover, according to Girish and Kemparaju [99], aristolochic acid I is an inhibitor of hyaluronidase of Naja naja venom. 
Hyaluronidase is one of the most widely distributed components of snake venom and has been characterized as a substance that aids in the spread of venom due to its ability to promote local hemorrhage. Consequently, the inhibition of hyaluronidase helps reduce both local tissue damage and the magnitude of the systemic effects of envenomation [100]. Figure 2 shows the selected phenolic compounds with antivenom activity.<smiles>COc1cc(O)c2c(c1)oc(=O)c1c3cc(O)c(O)cc3oc21</smiles>

Wedelolactone<smiles>COC1=Cc2c(oc3cc(O)c(O)cc23)C2=CC=C(O)C=C1O2</smiles>

8-Methoxy coumestrol<smiles>COc1c2c(c(OC)c3oc(=O)ccc13)O[C@@H](C(C)(C)O)C2</smiles>

Alternamin<smiles>O=C(/C=C/c1ccc(O)c(O)c1)OC(Cc1ccc(O)c(O)c1)C(=O)O</smiles>

Rosmarinic Acid<smiles>Oc1ccc(/C=C/c2cc(O)cc(O)c2)cc1</smiles>

Resveratrol<smiles>O=C(/C=C/c1ccc(O)c(O)c1)O[C@H]1C[C@](O)(C(=O)O)C[C@H](O)[C@H]1O</smiles>

Chlorogenic acid<smiles>O=C(O)[C@]1(O)C[C@@H](O)[C@H](O)[C@H](O)C1</smiles>

Quinic acid<smiles>COc1ccc(C(=O)O)c(O)c1</smiles>

2-Hydroxy-4-methoxy-benzoic acid<smiles>O=C(O)c1cc(O)c(O)c(O)c1</smiles>

Gallic acid<smiles>C=CC(C)(CC/C=C(\C)CCC=C(C)C)c1ccc(O)c(O)c1</smiles>

4-Nerolidyl-catechol<smiles>O=c1oc2c(O)c(O)cc3c(=O)oc4c(O)c(O)cc1c4c23</smiles>

Ellagic acid<smiles>COc1cccc2c1cc([N+](=O)[O-])c1c(C(=O)O)cc3c(c12)OCO3</smiles>

Aristolochic acid I

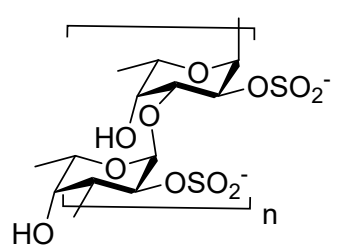

Fucoidan<smiles>O=C(OCCCOC(=O)c1cc(O)c(O)c(O)c1)c1cc(O)c(O)c(O)c1</smiles>

1,2,3,4,6-Pentagalloyl glucopyranoside

Figure 2. Selected phenolic compounds and the fucoidan sugar with antivenom activity.

Flavonoids are known for their wide range of health benefits and are commonly used in various ailments. The polypharmacological profile of flavonoids as anti-inflammatory, anti-mutagenic, and anti-carcinogenic agents is due to their ability to modulate key cellular enzyme functions; for example, xanthine oxidases, cyclooxygenases, and kinases [101]. It is because of these properties that flavonoids are active against several snake venoms, examples of which are shown in Figure 3. Dietary flavonoids, such as catechin, quercetin, luteolin, kaempferol, myrcetin, and apigenin, display 
high inhibition of venom hyaluronidases [102]. Reports show that pinostrobin is the bioactive component of Renealmia alpinia that inhibited the phospholipase A2 in Crotalus durissimus venom and displayed anti-hemorrhagic and analgesic activities in Bothrops asper snake venom [103]. Myricetin exhibited proteolytic and hemorrhagic activities along with the inhibition of the enzymatic activity of zinc metalloprotease of B. atrox venom [104]. Quercetin-3-O-rhamnoside has shown strong inhibition of phospholipase A2 and anti-hemorrhagic activity for Naja naja venom [105]. Recently, rutin, another well-known dietary flavonoid with antioxidant property, ameliorated coagulation disorders involved in Bothrops jararaca envenomation [106]. Isoflavonoids, a subclass of flavonoids, are frequently found in free form in a great variety of plants. Isoflavonoids have been reported to be active against the snake venoms, cabenegrins AI and A-II from Annona coriacea (Annonaceae). They are known to reverse the toxic effects of the B. atrox venom in dog models; however, no mechanism has been reported [107]. Edunol from Brongniartia podalyrioides (Leguminosae) reversed the toxic effects of B. atrox envenomation in rodent models [45]. Harpalycin 2 (HP-2) isolated from Harpalyce brasiliana (Papilionoideae) inhibited the enzymatic acitivity of piratoxin-III isolated from the venom of Bothrops pirajai [108].<smiles>Oc1cc(O)c2c(c1)O[C@H](c1ccc(O)c(O)c1)[C@H](O)C2</smiles><smiles>COc1cc(O)c2c(c1)OC(c1ccccc1)CC2=O</smiles><smiles>O=c1cc(-c2ccc(O)c(O)c2)oc2cc(O)cc(O)c12</smiles><smiles>O=c1c(O)c(-c2ccc(O)c(O)c2)oc2cc(O)cc(O)c12</smiles>

Quercetin-3-O- $\alpha$ - rhamnopyranoside<smiles>COc1cccc2oc(-c3cc(O)c(O)c(O)c3)c(O)c(=O)c12</smiles>

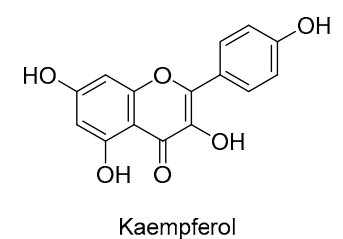<smiles>CC(=CCc1c(O)ccc2c1OCC2c1cc2c(cc1O)OCO2)CO</smiles>

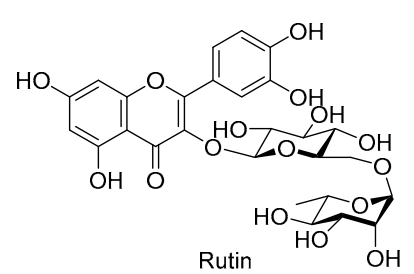<smiles>CCCCCCCCC</smiles><smiles>CC(CO)CCc1cc2c(cc1O)OCC1c3cc4c(cc3OC21)OCO4</smiles><smiles>CC1(C)Oc2cc3occ(-c4ccc5c(c4)OCO5)c(=O)c3c(O)c2CC1O</smiles>

Figure 3. Selected flavonoids with antivenom activity.

Terpenes are a combination of isoprene units and display a wide range of biological properties and therapeutic uses [109]. There are several examples of monoterpenes, sesquiterpenes, diterpenes, triterpenoids, and steroids, and their glycosides that have been used to treat the effects of snakebites. Selected examples are shown in Table 2 and Figure 4. Linearol and isolinearol isolated from the brown algae Canistrocarpus cervicornis inhibited hemolysis, proteolysis, and hemorrhage in Bothrops jararaca envenomation [110]. Steroids such as sitosterol, stigmasterol, and campesterol, and pentacyclic triterpenoids such as lupeol showed anti-hemorrhagic and anti-lethality properties against several snake venoms due to their antioxidant properties [85]. Triterpene (CAS \# 1260387-36-7) exhibited phospholipase A2 activity [111]. A typical example is the metalloproteinase activity displayed by the heptaglycoside saponins, macrolobins A and B (Figure 5) [112]. Betulinic, oleanoic, and ursolic 
acids have shown potent metalloproteinase inhibition and proteolytic activity for Bothrops atrox venom, which are evident from computational studies [113]. Dolastane, a diterpene isolated from the extract of the marine brown algae Canistrocarpus cervicornis (Dictyotaceae) was found to inhibit hemorrhage, hemolysis, and coagulation induced by the venom of Lachesis muta [114]. Oleanolic acid, a triterpenoid, known for its anti-inflammatory property, is commonly present in several medicinal plants. Oleanolic acid inhibited the activities of $\mathrm{SPLA}_{2}$ (a significant enzyme involved in inflammatory reactions) of human pleural fluid (HPF), human synovial fluid (HSF), Vipera russelli, and Naja naja snake venoms [115].

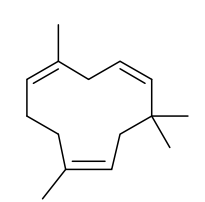

$\alpha$-Humulene<smiles>C=C1CC[C@H](OC(C)=O)[C@@]2(C)CC=C3[C@](C)(CC[C@@]3(O)C(C)C)C[C@]12O</smiles>

CAS \# 88452-92-0

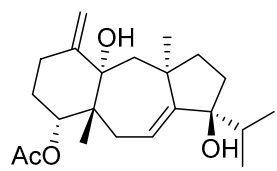

Dolastane<smiles>C/C=C\CCCCCCCCCCC</smiles>

trans-Caryophyllene<smiles>C=C1C[C@]23C[C@@H]1CC[C@H]2[C@@]1(C)CC[C@H](O)[C@](C)(COC(C)=O)[C@H]1C[C@H]3O</smiles>

Linearol<smiles>CC1=CCC2CC1C2(C)C</smiles>

$\alpha$-Pinene<smiles>C=C1CC[C@@H]2[C@H](C1C)[C@@H]1C(C)CCC(C)[C@@H]1C2(C)C</smiles>

Alloaromadendrene

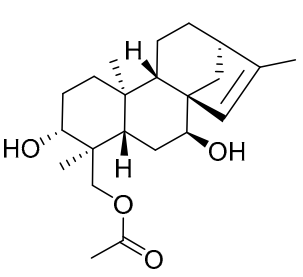<smiles>CC1CCCCCCCCC23CCCC=C2C(=O)OC3C1O</smiles>

Isolinearol

$7 \alpha$-Hydroxy-3,13-clerodadiene16,15:18,19-diolide<smiles>CCC(CC[C@H](C)[C@H]1CC[C@H]2[C@@H]3CC=C4C[C@@H](O)CC[C@]4(C)[C@H]3CC[C@@]21C)C(C)C</smiles>

$\beta$-Sitosterol<smiles>CCC(/C=C/C(C)[C@H]1CCC2C3C=CC4CC(O)CCC4(C)C3CCC21C)C(C)C</smiles>

Stigmasterol<smiles>CC1(C)CCC2(C(=O)O)CC[C@H]3C(=CCC4[C@@]5(C)CC[C@@H](O)C(C)(C)[C@H]5CC[C@]43C)[C@]2(C)C1</smiles><smiles>CC(C)[C@H](C)CC[C@H](C)[C@H]1CC[C@H]2[C@@H]3CC=C4C[C@@H](O)CC[C@]4(C)[C@H]3CC[C@@]21C</smiles>

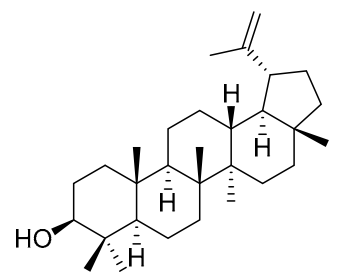

Lupeol

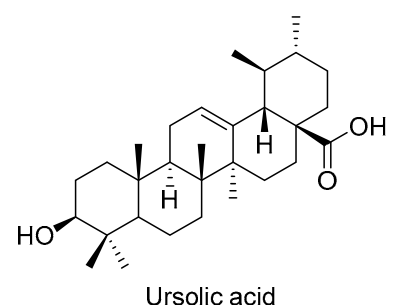<smiles>CC1CC2(CCC1O)C(C)CCC1C2CC=C2C3CC(C(=O)O)CCC3(C)CCC21C</smiles>

CAS \# 1260387-36-7

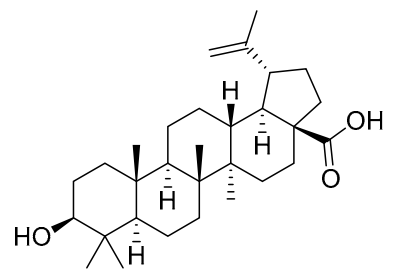

Betulinic acid

Figure 4. Selected terpenoids with antivenom activity. 


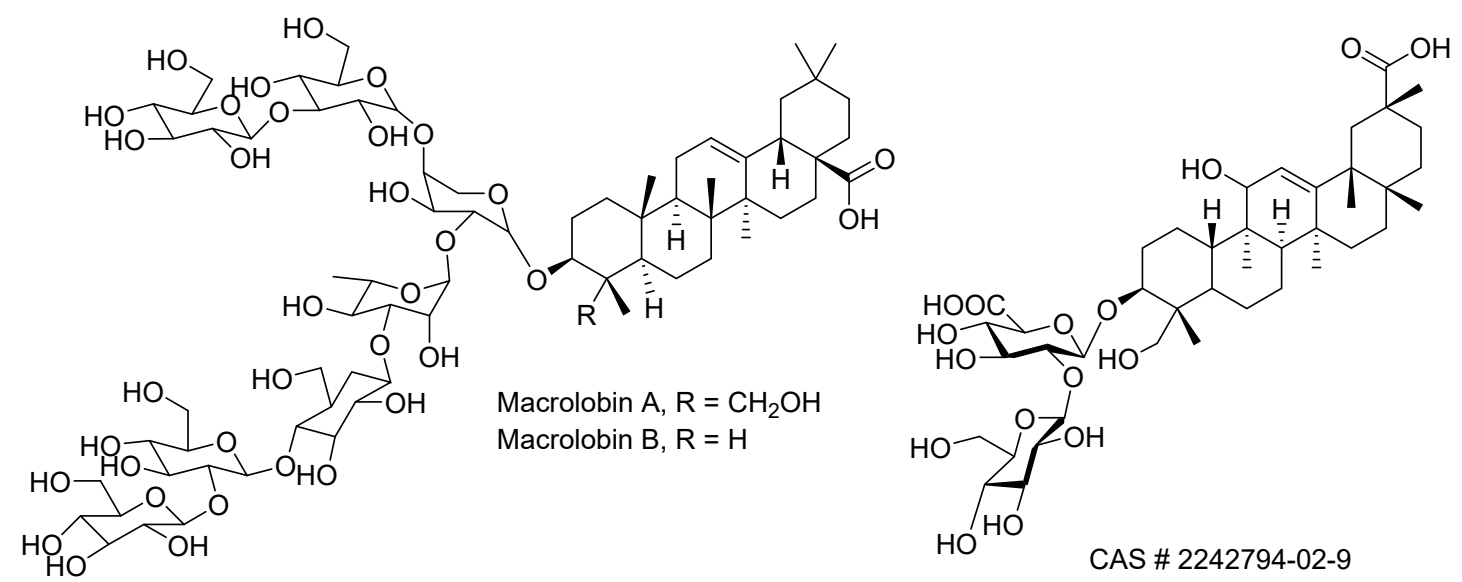

Figure 5. Selected saponins with antivenom activity.

There are several examples of alkaloids with antivenom properties (Table 2, Figure 6). In the year 2000, it was reported that the compound 12-methoxy-4-methyl voachalotine isolated from the roots of Tabernaemontana catharinensis was able to neutralize the lethality and myotoxicity induced by Crotalus durissus venom [116]. Lately, it was found that the latex of T. catharinensis has several other indole alkaloids that are potential candidates for screening against snake phospholipases and metalloproteases [117].

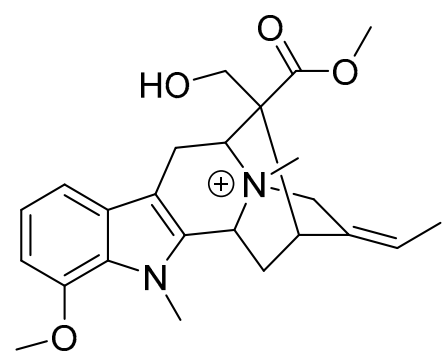

12-methoxy-4-methyl-voachalotine<smiles>C[C@H]1CC[C@@H]2CN1[C@H]1[C@H](C[C@H]3C4CCC5CCCC[C@]5(C)C4CC[C@@]31C)[C@@H]2C</smiles>

Solanidane

Figure 6. Selected alkaloids with antivenom activity.

Table 2 summarizes a list of isolated bioactive compound and their mechanisms of action. 
Table 2. List of isolated bioactive compounds with venom neutralization capabilities and their mechanisms of action.

\begin{tabular}{|c|c|c|c|c|}
\hline Compound & Source & Mechanism of Action & Mode of Administration/Study Level & Reference \\
\hline Aristolochic acids & $\begin{array}{l}\text { Aristolochia indica } \\
\text { Aristolochia sp. } \\
\text { Aristolochia odoratissima } \\
\text { Aristolochia fordiana } \\
\text { Aristolochia radix }\end{array}$ & $\begin{array}{l}\text { Induction of } \mathrm{PLA}_{2} \\
\text { Inhibition of L-amino acid oxidase } \\
\text { Anti-lethality }\end{array}$ & Injected into the mouse foot pad & {$[96-99,118-121]$} \\
\hline Rosmarinic acid & $\begin{array}{l}\text { Cordia verbenacea } \\
\text { Argusia argentea }\end{array}$ & $\begin{array}{c}\text { Inhibition of myotoxic activity and } \text { PLA }_{2} \\
\text { Anti-hemorrhagic activity }\end{array}$ & $\begin{array}{l}\text { Injected intramuscularly into the right } \\
\text { gastrocnemius muscle of mice } \\
\text { In vivo study }\end{array}$ & [122-125] \\
\hline $\begin{array}{l}\text { Quercetin-3-O- } \alpha \text {-L-rhamnopyranoside } \\
\text { quinic acid, gallic acid, quercetin, kaempferol, } \\
\text { luteolin, ellagic acid, chlorogenic acid }\end{array}$ & Euphorbia hirta & Inhibition of $\mathrm{PLA}_{2}$ & In vitro study & {$[105,126]$} \\
\hline Pinostrobin & Renealmia alpinia & Inhibition of myotoxic activity and PLA $_{2}$ & $\begin{array}{l}\text { Intramuscular injection (inhibition of } \\
\text { myotoxic activity) and subcutaneous } \\
\text { injection (inhibition of edema-inducing } \\
\text { activity) }\end{array}$ & [81] \\
\hline Undisclosed & Azadirachta indica & Inhibition of $\mathrm{PLA}_{2}$ & In vitro study & [127] \\
\hline 2-hydroxy-4-methoxy benzoic acid & Hemidesmus indicus & $\begin{array}{l}\text { Neutralization of venom hemorrhagic } \\
\text { activity }\end{array}$ & Injected intradermally into mice & [128] \\
\hline$\beta$-sitosterol & $\begin{array}{l}\text { Eclipta prostrata, Humirianthera ampla } \\
\text { Cynanchum paniculatum }\end{array}$ & Neutralization of enzymes & In vitro and in vivo studies & [129-131] \\
\hline $\begin{array}{l}\text { 7 } \alpha \text {-hydroxy-3,13-clerodadiene-16,15:18,19- } \\
\text { diolides }\end{array}$ & Baccharis trimera & Inhibition of metalloproteases & In vitro and in vivo studies & [133] \\
\hline $\begin{array}{l}\text { CAS \# 1260387-36-7 } \\
\text { CAS \# 2242794-02-9 }\end{array}$ & Clematis gouriana & Inhibition of $\mathrm{PLA}_{2}$ & In vitro and computational studies & {$[111]$} \\
\hline $\begin{array}{c}\text { Linearol } \\
\text { Isolinearol } \\
\text { CAS \# 88452-92-0 }\end{array}$ & Canistrocarpus cervicornis & $\begin{array}{l}\text { Inhibition of induced hemorrhage, } \\
\text { hemolysis, and coagulation }\end{array}$ & Biological assays & {$[110,114]$} \\
\hline Ellagic acid & Casearia silvestris & Anti-myotoxic and anti-edema & In vivo study & {$[134,135]$} \\
\hline Resveratrol & Crinum jagus & $\begin{array}{c}\text { Neutralization of } \mathrm{PLA}_{2} \text {, protease, } \\
\text { hyaluronidase, L-amino acid oxidase, and } \\
5^{\prime} \text {-nucleotidase enzyme activities. } \\
\text { Anti-myonecrosis and anti-hemorrhagic }\end{array}$ & $\begin{array}{l}\text { Oral and intraperitoneal administration. } \\
\text { In vivo study }\end{array}$ & {$[136,137]$} \\
\hline $\begin{array}{l}\text { Campesterol, } \beta \text {-sitosterol (its glycoside), } \\
\text { stigmasterol, catechin, and gallocatechin }\end{array}$ & Croton urucurana & Anti-hemorrhagic and anti-lethality & In vivo study & [138] \\
\hline
\end{tabular}


Table 2. Cont

\begin{tabular}{|c|c|c|c|c|}
\hline Compound & Source & Mechanism of Action & Mode of Administration/Study Level & Reference \\
\hline $\begin{array}{c}\text { Rosmarinic acid } \\
\alpha \text {-Humulene } \\
(-)-\text { trans-Caryophyllene } \\
\alpha \text {-Pinene and alloaromadendrene }\end{array}$ & Cordia verbenacea & $\begin{array}{l}\text { Anti-inflammatory, anti-myotoxic, } \\
\text { anti-edematogenic, and anti-PLA } \mathrm{A}_{2} \text { activity. } \\
\text { Anti-edematogenic and reduction of tumor } \\
\text { necrosis factor- } \alpha(\mathrm{TNF} \alpha) \\
\text { Reduction of platelet activating factor, } \\
\text { bradykinin, and anti-edematogenic. } \\
\text { Anti-inflammatory and anti-edematogenic }\end{array}$ & In vivo study & {$[87,122,139,140]$} \\
\hline Fucoidan & Fucus vesiculosus & $\begin{array}{l}\text { Anti-myotoxic activity, anti-PLA } 2 \text {, and } \\
\text { anti-necrosis }\end{array}$ & In vivo study & [141] \\
\hline Wedelolactone & Eclipta alba & $\begin{array}{l}\text { Anti-hepatotoxic, anti-hypertensive, } \\
\text { anti-tumor, anti-PLA } A_{2} \text {, anti-snake venom, } \\
\text { and anti-myotoxic-induced PLA } \text { PL }_{2} \text {. }\end{array}$ & In vivo study & [142-144] \\
\hline Wedelolactone, sitosterol, and stigmasterol & Eclipta prostrata & Anti-neurotoxic and anti-myotoxic & In vivo study & [145] \\
\hline $\begin{array}{l}\text { 2-hydroxy-4-methoxy-benzoic acid and } \\
\text { lupeol acetate }\end{array}$ & Hemidesmus indicus & $\begin{array}{l}\text { Anti-defibrinogenatic, anti-edematogenic, } \\
\text { anti-PLA }{ }_{2} \text { activity, anti-necrotic, } \\
\text { anti-hemorrhagic, anti-coagulant, lipid } \\
\text { peroxidase inhibition, superoxide } \\
\text { dismutase activity, antiserum action } \\
\text { potentiation, anti-lethality, anti-cardiotoxic, } \\
\text { and anti-neurotoxic }\end{array}$ & In vivo study & {$[78,79,128,146]$} \\
\hline Pentagalloyl glucopyranose & Mangifera indica & $\begin{array}{l}\text { Anti-hemorrhagic, anti-dermonecrotic, and } \\
\text { enzymatic activities. } \\
\text { Inhibition of protease, hyalunoridase, } \\
\text { fibrinogenolytic, procoagulant, } \\
\text { anti-edematogenic, anti-ATPase, and } \\
\text { alkaline phosphatase }\end{array}$ & In vivo study & {$[60,83]$} \\
\hline Gallic acid & Musa paradisiaca & $\begin{array}{l}\text { Anti-PLA } A_{2,} \text { anti-myotoxic, } \\
\text { anti-hemorrhagic, and anti-lethality }\end{array}$ & In vivo study & {$[109,147]$} \\
\hline Alternamin & Murraya alternans & Anti-hemorrhagic & In vivo study & {$[148]$} \\
\hline Macrolobins A and B & Pentaclethra macroloba & $\begin{array}{c}\text { Anti-proteolytic and anti-hemorrhagic, } \\
\text { metalloprotease inhibitors }\end{array}$ & In vitro and in vivo studies & [112] \\
\hline 4-Nerolidyl-catechol & $\begin{array}{l}\text { Piper umbellatum and } \\
\text { Piper peltatum }\end{array}$ & $\begin{array}{c}\text { Anti-myotoxic, anti-PLA, } \\
\text { anti-serineprotease, and anti-edematogenic }\end{array}$ & In vivo study & [42] \\
\hline Solanidane & Solanum campaniforme & $\begin{array}{l}\text { Hemorrhagic inhibitor, necrotizing, and } \\
\text { myotoxicity effects }\end{array}$ & In vivo study & [149] \\
\hline 12-methoxy-4-methyl-voachalotine & Tabernaemontana catharinensis & Inhibited lethality & In vivo study & {$[116,117]$} \\
\hline Whitania Somnifera Glycoprotein (WSG) & Withania somnifera & Anti-edematogenic & In vivo study & [150] \\
\hline $\begin{array}{l}\beta \text {-sitosterol, quercetin-3-O-glucopyranoside, } \\
\text { and kaempferol-3-O-glucopyranoside }\end{array}$ & Morus nigra & $\begin{array}{l}\text { Anti-inflammatory and antinociceptive } \\
\text { effects }\end{array}$ & In vivo study & [151] \\
\hline
\end{tabular}


Table 2. Cont.

\begin{tabular}{|c|c|c|c|c|}
\hline Compound & Source & Mechanism of Action & Mode of Administration/Study Level & Reference \\
\hline 2-hydroxy-3-methoxy benzaldehyde & Janakia arayalpathra & Anti-PLA ${ }_{2}$ & In vitro study & [92] \\
\hline Marmin & Aegle marmelos & Anti-snake venom & In vivo study & [85] \\
\hline Cabenegrins AI and A-II & Annona coriaceae & Anti-snake venom & In vitro and in vivo studies & {$[107]$} \\
\hline Boc- 5 and Boc-10 (sulfated galactans) & Botryocladia occidentalis & $\begin{array}{l}\text { Anti-edematogenic, anti-myotoxic, and } \\
\text { anti-neurotoxic }\end{array}$ & In vivo study & [152] \\
\hline Edunol & Brongniartia podalyrioides & $\begin{array}{l}\text { Protective effect against Bothrops atrox } \\
\text { venom }\end{array}$ & In vivo study & [45] \\
\hline Dolastane & Canistrocarpus cervicornis & $\begin{array}{l}\text { Inhibition of induced hemorrhaging, } \\
\text { hemolysis, and coagulation }\end{array}$ & In vitro and in vivo studies & [116] \\
\hline Manoalide & Luffariella variabilis & $\begin{array}{l}\text { Inhibition of extracellular } \mathrm{PLA}_{2} \text { activity of } \\
\text { cobras }\end{array}$ & In vitro study & [153] \\
\hline DM64 (acidic glycoprotein) & Didelphis marsupialis & $\begin{array}{l}\text { PLA }_{2} \text { inhibitor and prevention of myofiber } \\
\text { breakdown caused by myotoxins I (Asp49) } \\
\text { and II (Lys49) of B. asper venom }\end{array}$ & In vitro and in vivo studies & [154] \\
\hline $\begin{array}{c}\text { Aristolochic acid (8-methoxy-6- } \\
\text { nitrophenanthro(3,4-d)-1,3-dioxole-5- } \\
\text { carboxylic acid) } \\
\text { Caffeic acid (3-(3,4-dihydroxyphenyl)-2- } \\
\text { propenoic acid) }\end{array}$ & $\begin{array}{l}\text { Aristolochia species } \\
\text { Vernonia condensate }\end{array}$ & $\begin{array}{l}\text { Inhibition of piratoxin-1 (PrTX-1), a } \\
\text { Lys49-PLA } 2 \text { isolated from Bothrops pirajai } \\
\text { venom } \\
\text { Inhibition of PrTX-1 and antidote activity } \\
\text { against } B \text {. jararaca venom }\end{array}$ & $\begin{array}{l}\text { Oral or parenteral administration } \\
\text { In vitro and in vivo studies }\end{array}$ & $\begin{array}{c}{[85,119]} \\
{[121]}\end{array}$ \\
\hline
\end{tabular}




\section{Drawbacks of Herbal Products in the Treatment of Snake Envenomation}

In general, the practice of traditional medicine is largely based on the use of plant derivatives, which can be classified into two classes: herbs found in databases that provide a detailed description and proof for their use in historical reports (for example, herbs used in traditional Chinese medicine and Ayurvedic medicine), and herbs used in folk medicine that lack bibliographic information and are transmitted verbally. It is undeniable that the development of many drugs in modern medicine is still based on clinical experiences of traditional medicines and therapies. A unique example is China, with at least 130 new drugs currently in clinical use that are unique chemical entities extracted from either medicinal herbs or synthetically modified compounds [155]. Some examples are anisodamine [156], indirubin [157], huperzine [158], and bicyclol [159]. Currently, the development of drugs, especially antivenoms and phyto-antivenoms, face three major challenges: the amount of time consumed, money spent, and potential toxicity of the obtained products. In this regard, traditional knowledge and pragmatic databases derived from clinical practice are fundamental to increase the success rate of drug discovery compared to the conventional approaches, which include isolation, screening, and chemical synthesis, leading to longer times. According to Si-Yuan Pan et al. [30], some of these databases are: Traditional Chinese Medicine Information Database (TCHM-ID), Traditional Chinese Medicines Integrated Database (TCMID), The Herb Information Knowledge Base (THINKherb), and Indian Plant Anticancer Compounds database (InPACdb). Available databases in drug discovery include: Online Mendelian Inheritance in Man (OMIM), World Molecular Bioactivity (WOMBAT), Therapeutic Targets Database (TTD), PubChem, DrugBank, BioAssay, and Potential Drug Target Database (PDTD).

According to Laustsen and Dorrestijn [160], there is a need to provide safe, affordable, and effective antivenoms to victims of snakebites worldwide. It is important to take advantage of new biotechnological approaches for the development of new antivenoms. These could be based on mixtures of human monoclonal antibodies that could directly replace the polyclonal equine antibodies that are currently being used in conventional antivenoms.

\section{Challenges Involved in the Discovery of Antivenoms}

The discovery of new antivenoms involves significant challenges in the assessment, design, and production of potential antivenoms, and the refinement of current compounds to better meet the needs. New and much improved antivenoms with high standards can be produced in adequate volumes when multidisciplinary, international collaborative efforts are undertaken. This would help serve not a particular nation but entire regions [161].

The initial strategy included developing antibodies in sheep rather than in horses to refine Fab fragments in order to hasten tissue distribution and reduce the risk of anaphylactic reactions. This strategy was discontinued due to rapid renal elimination of Fab fragments and the need for recurrent envenoming [162]. Proteomic investigation of snake venoms is another strategy that needs to be determined, characterized, and harnessed for bioactive toxins in drug discovery. Proteomics support not only the design improvement of both antivenoms and immunogen mixtures but also provide a mechanism to evaluate the suitability of both existing and potential antivenoms [162]. In order to simplify proteomes, removal of highly abundant proteins was commonplace, which was later discontinued due to the loss of numerous minor species along with target proteins [161].

The combinatorial peptide library approach utilizes the snake venom protocol to mine and complement the gained data for comprehensive visualization of the venom proteome [163-165]. Another approach is the peptide inhibitor approach. In order for this approach to be successful, the inhibitors are required to have smaller molecular sizes and should not be immunogenic in nature, which might cause cross-reaction with acetylcholine receptors (AChR), resulting in myasthenia gravis, an autoimmune disease [161]. The phage display library is an alternative approach for the identification of epitopes in several proteins and toxins to find peptides that can bind to toxins (mimotopes) or antibodies specific against toxins. The benefit of this approach is conformation and that the linear epitopes are recognized from their corresponding mimotopes $[161,166]$. Synthetic 
biology is another approach to increase the production of antivenoms as compared to conventional methods. This approach involves the injection of small pieces of synthetic venom antibodies that are synthesized in Escherichia coli to boost the animal's immune response. The advantage with synthetic biology is that the antivenoms produced through this approach result in less muscle damage and tissue death at the site of the bite, as these antibodies are smaller and better able to penetrate the tissue [165]. Development of a single optimized nanoparticle (NP) formulation led to the possibility of broad spectrum neutralization and sequestration of venomous biomacromolecules. This led to the possibility of broad spectrum antivenoms. The major challenge with this approach is the selectivity for the targeted venom proteins over other copious serum proteins when developing the polymer sequestrant [167].

\section{Snake Venom as a Source of Therapeutic Agents}

Although snake venom is fatal in itself, it is known to possess various toxin peptides with significant bioactivities [22,168]. Tirofiban and eptifibatide are FDA-approved antiplatelet drugs, which are disintegrin derivatives from Echis carinatus and Sistrurus miliarus barbouri, respectively [169]. Captopril is a FDA-approved antihypertensive drug, which is a derivative of bradykinin potentiating peptide obtained from Bothrops jaracusa [170]. Hemocoagulase and batroxobin are marketed drugs in some countries outside of the United States for the treatment of hemorrhage and as a defibrinogenating agent, respectively. Hemocoagulases are thrombin- and thromboplastin-like enzymes obtained from Bothrops atrox, while batroxobin is a serine protease derived from Bothrops moojeni and B. atrox. Batroxobin can be a potential tool in patients on anticoagulant therapy for surgical hemostasis [171]. Ximelagatran is a peptide isolated from cobras, which was once a FDA-approved drug as an anticoagulant, but is now withdrawn from the market. Ancrod was also an FDA-approved drug as a defibrinogenating agent, which was later withdrawn and is currently under phase III clinical studies. Ancrod is an enzyme from Agkistrodon rhodostoma. Dendroaspis-NP is currently under phase II clinical study for the treatment of congestive cardiac failure. It is isolated from Dendroaspis angusticeps and is a natriuretic peptide. Furthermore, $\alpha$-Cobratoxin and $\alpha$-cobrotoxin are neurotoxins isolated from Naja kaouthia and Naja nivea, respectively. These neurotoxins are currently undergoing human trials as analgesics in China [172].

The two crucial New Guinean species used in the production of anti-venom are Oxyuranus scutellatus and Acanthophis laevis. Major species of South and Southeast Asian snakes used in antivenom production include Calloselasma rhodostoma, Echis carinatus, Naja spp., Daboia spp., Bungarus spp., and Cryptelytrops spp. In Africa, species belonging to Cerastes, Dendroaspis, Naja, Bitis, and Echis genera are significant for antivenom production [161].

Venom is a mixture of peptides, proteins, and other small molecules with varied pharmacological properties. There are many bioactive venom peptides from undiscovered sources that could result in potentially new therapeutic leads. The low approval rate of venom peptides could be due to problems such as the low stability and bioavailability of these peptides. Introduction of peptidomimetics into the organic compounds could be a solution to overcome the above problems by mimicking the peptide action [172].

\section{Conclusions}

Natural products are biodiverse in nature and can be invaluable resources that can contribute to the continuous improvement of the development of products that act as co-adjuvants and can help neutralize the action of venom toxins. As drug discovery from natural sources has traditionally been time-consuming, faster and better methodologies for bioassay screening, compound isolation, and compound development must be employed. Even with all the limitations facing drug discovery, natural products isolated from medicinal plants remain as the essential tools in the search for new medicines. Although there are many studies with clear evidence of the effectiveness of herbal treatments for snake bites, very few of these studies have clinical corroboration. Therefore, it is important that the 
use of such plants for the treatment of snake bites should be performed with caution until efficiency can be confirmed. In this review, we focused on the collection of data from isolated plants and compounds that are most commonly used in the treatment of snakebites. The continuation of research in this area is urgent, especially in rural areas of countries that have received less attention. Novel approaches should be recognized for the identification of active ingredients to treat snakebites, and the continuum of the virtual methods can expedite the process though analytical chemistry tools. With thousands of plant species on the planet, there is a wide diversity of sources to obtain medicinal remedies from nature. Due to the low success rate and the huge need for capital investment, the research and development of conventional drugs is very expensive and difficult to achieve. Consequently, researchers have focused their efforts on discovering drugs from natural sources. The exceptional knowledge transmitted by indigenous and rural communities regarding the use of plants for the treatment of various diseases should be used to improve the success rate of the development of new drugs or phytotherapeutics. Since this process is initially based on experience, and therefore has a known approach, the search for therapeutically useful synthetic drugs implies greater difficulty and is a daunting task. The use of synthetic biology has appeared to revolutionize drug discovery, and hence there are fewer success stories without serious and unpredictable complications.

We are living in a post-genomic era, and therefore, the prospect of the drug discovery from herbal medicines and other organisms is growing. Ongoing efforts involve the use of advancements in science and technology for the development of new and better processes that could ultimately lead to novel and efficient drugs. Pharmaceutical companies face a great challenge in exploring new forms of research and development in drug discovery, and hence, it is necessary that they become cognizant of both herbal medicines and other sources of bioactive compounds. Small molecules with different natural scaffolds have the potential to act as a single entity or as a mixture to affect the modulation of the toxic enzymes present in snake venoms. Increased research towards the development of bioactive natural products as lead compounds to overcome the need for novel antivenoms is essential.

Funding: This research received no external funding.

Acknowledgments: The authors are grateful to Ophidism and Scorpionism Program of the University of Antioquia (Colombia).

Conflicts of Interest: The authors have no relevant affiliations or financial involvement with any organization or entity with a financial interest in or financial conflict with the subject matter or materials discussed in the manuscript. This includes employment, consultancies, honoraria, stock ownership or options, expert testimony, grants or patents received or pending, or royalties. The authors declare that they have no conflict of interest.

\section{References}

1. WHO. Available online: https://www.who.int/neglected_diseases/EB132_R7_en.pdf (accessed on 5 March 2019).

2. Warrell, D.A.; Gutiérrez, J.M.; Calvete, J.J.; Williams, D. New approaches \& technologies of venomics to meet the challenge of human envenoming by snakebites in India. Indian J. Med Res. 2013, 138, 38-59. [PubMed]

3. WHO. Available online: https://www.who.int/snakebites/en/ (accessed on 9 September 2018).

4. Fry, B.G. Snakebite: When the Human Touch Becomes a Bad Touch. Toxins 2018, 10, 170. [CrossRef] [PubMed]

5. Ralph, R.; Sharma, S.K.; Faiz, M.A.; Ribeiro, I.; Rijal, S.; Chappuis, F.; Kuch, U. The timing is right to end snakebite deaths in South Asia. BMJ 2019, 364, k5317. [CrossRef] [PubMed]

6. WHO. Guidelines for the Production, Control and Regulation of Snake Antivenom Immunoglobulins. Available online: https://www.who.int/bloodproducts/snake_antivenoms/snakeantivenomguide/en/ (accessed on 9 December 2018).

7. Gutiérrez, J.M.; Calvete, J.J.; Habib, A.G.; Harrison, R.A.; Williams, D.J.; Warrell, D.A. Snakebite envenoming. Nat. Rev. Dis. Primers 2017, 14, 17063.

8. Kini, R.M.; Doley, R. Structure, function and evolution of three-finger toxins: Mini proteins with multiple targets. Toxicon 2010, 56, 855-867. [CrossRef] [PubMed]

9. Gutiérrez, J.M. Understanding and confronting snakebite envenoming: The harvest of cooperation. Toxicon 2016, 109, 51-62. [CrossRef] 
10. Chippaux, J.P.; Goyffon, M. Venomous and poisonous animals. I. Overview. Med Trop 2006, 66, $215-220$.

11. Giovannini, P.; Howes, M.-J.R. Medicinal plants used to treat snakebite in Central America: Review and assessment of scientific evidence. J. Ethnopharmacol. 2017, 199, 240-256. [CrossRef]

12. Félix-Silva, J.; Silva-Junior, A.A.; Zucolotto, S.M.; Fernandes-Pedrosa, M.D.F. Medicinal plants for the treatment of local tissue damage induced by Snake Venoms: An overview from traditional use to pharmacological evidence. Evid Based Complement. Alternat. Med. 2017, 5748256. [CrossRef]

13. Upasani, S.V.; Beldar, V.G.; Tatiya, A.U.; Upasani, M.; Surana, S.J.; Patil, D.S. Ethnomedicinal plants used for snakebite in India: A brief overview. Integr. Med. Res. 2017, 6, 114-130. [CrossRef]

14. Bermúdez-Méndez, E.; Fuglsang-Madsen, A.; Føns, S.; Lomonte, B.; Gutiérrez, J.M.; Laustsen, A.H. Innovative Immunization Strategies for Antivenom Development. Toxins 2018, 10, 452. [CrossRef] [PubMed]

15. Landon, J.; Smith, D.S. Merits of Sheep Antisera for Antivenom Manufacture. J. Toxicol. Toxin Rev. 2003, 22, 15-22. [CrossRef]

16. Aird, S.D. Ophidian envenomation strategies and the role of purines. Toxicon 2002, 40, 335-393. [CrossRef]

17. Heard, K.; O'Malley, G.F.; Dart, R.C. Antivenom therapy in the Americas. Drugs 1999, 58, 5-15. [CrossRef] [PubMed]

18. De Silva, H.A.; Ryan, N.M.; de Silva, J. Adverse reactions to snake antivenom, and their prevention and treatment. Br. J. Clin. Pharmacol. 2016, 81, 446-452. [CrossRef] [PubMed]

19. Guimaraes, C.L.S.; Moreira-Dill, L.S.; Fernandes, R.S.; Costa, T.R.; Hage-Melim, L.I.S.; Marcussi, S.; A Carvalho, B.M.; Da Silva, S.L.; Zuliani, J.P.; Fernandes, C.F.C.; et al. Biodiversity as a source of bioactive compounds against snakebites. Curr. Med. Chem. 2014, 21, 2952-2979. [CrossRef] [PubMed]

20. Chippaux, J.-P. Estimating the Global Burden of Snakebite Can Help to Improve Management. PLoS Med. 2008, 5, e221. [CrossRef] [PubMed]

21. Kini, R.M.; Sidhu, S.S.; Laustsen, A.H. Biosynthetic Oligoclonal Antivenom (BOA) for Snakebite and Next-Generation Treatments for Snakebite Victims. Toxins 2018, 10, 534. [CrossRef] [PubMed]

22. Laustsen, A.; Engmark, M.; Milbo, C.; Johannesen, J.; Lomonte, B.; Gutiérrez, J.; Lohse, B. From Fangs to Pharmacology: The Future of Snakebite Envenoming Therapy. Curr. Pharm. Des. 2016, 22, 5270-5293. [CrossRef]

23. Williams, H.E.; Layfield, H.J.; Vallance, T.; Patel, K.; Bicknell, A.B.; Trim, S.A.; Vaiyapuri, S. The Urgent Need to Develop Novel Strategies for the Diagnosis and Treatment of Snakebites. Toxins 2019, 11, 363. [CrossRef]

24. Dandona, R.; Kumar, G.A.; Kharyal, A.; George, S.; Akbar, M.; Dandona, L. Mortality due to snakebite and other venomous animals in the Indian state of Bihar: Findings from a representative mortality study. PLoS ONE 2018, 13, e0198900. [CrossRef] [PubMed]

25. Gummin, D.D.; Mowry, J.B.; Spyker, D.A.; Brooks, D.E.; Osterthaler, K.M.; Banner, W. Annual Report of the American Association of Poison Control Centers' National Poison Data System (NPDS): 35th Annual Report. Clin. Toxicol. 2017, 56, 1213-1415. [CrossRef] [PubMed]

26. Laustsen, A.H.; Gutiérrez, J.M.; Knudsen, C.; Johansen, K.H.; Méndez, E.B.; Cerni, F.A.; Jürgensen, J.A.; Ledsgaard, L.; Esteban, A.M.; Øhlenschlæger, M.; et al. Pros and cons of different therapeutic antibody formats for recombinant antivenom development. Toxicon 2018, 146, 151-175. [CrossRef] [PubMed]

27. Antivenin ${ }^{\circledR}$ [Prescribing Information]. Wyeth Lab. August 2001. Available online: https://www.fda.gov/ downloads/BiologicsBloodVaccines/UCM277363.pdf (accessed on 9 December 2018).

28. $\mathrm{CroFab}^{\circledR}$ [Prescribing Information]. BTG International Inc. May 2017. Available online: 17https://www.fda. gov/downloads/BloodBloodProducts/ucm117573.pdf (accessed on 9 December 2018).

29. Anavip ${ }^{\circledR}$ [Prescribing Information]. Rare Disease Therapeutics, Inc. May 2015. Available online: ttps://www.fda.gov/downloads/BiologicsBloodVaccines/BloodBloodProducts/ApprovedProducts/ LicensedProductsBLAs/FractionatedPlasmaProducts/UCM446175.pdf (accessed on 9 December 2018).

30. Scheske, L.; Ruitenberg, J.; Bissumbhar, B. Needs and availability of snake antivenoms: Relevance an application of international guidelines. Int. J. Health Policy Manag. 2015, 4, 447-457. [CrossRef] [PubMed]

31. Johnston, C.I.; Ryan, N.M.; Page, C.B.; Buckley, N.A.; Brown, S.G.; O'Leary, M.A.; Isbister, G.K. The Australian Snakebite Project, 2005-2015 (ASP-20). Med. J. Aust. 2017, 207, 119-125. [CrossRef] [PubMed]

32. Pan, S.Y.; Zhou, S.F.; Gao, S.H.; Yu, Z.L.; Zhang, S.F.; Tang, M.K.; Sun, J.N.; Ma, D.L.; Han, Y.F.; Fong, W.F.; et al. New Perspectives on How to Discover Drugs from Herbal Medicines: CAM's Outstanding Contribution to Modern Therapeutics. Evidence-Based Complement. Alternat. Med. 2013, 2013, 627375. [CrossRef] [PubMed] 
33. Lorenzi, H.; Matos, F.J.A. Plantas Medicinais no Brasil: Nativas e Exóticas; Instituto Plantarum de Estudos da Flora: São Paulo, Brasil, 2000.

34. Calderon, L.D.A.; Zuliani, J.P.; Da Silva, L.H.P.; Ii, I.; Silva-Jardim, I.; Silva, A.D.A.E.; Iii, I.; Ciancaglini, P.; Stábeli, R.G. Amazonian biodiversity: A view of drug development for leishmaniasis and malaria. J. Braz. Chem. Soc. 2009, 20, 1011-1023. [CrossRef]

35. Harvey, A.L.; Edrada-Ebel, R.; Quinn, R.J. The re-emergence of natural products for drug discovery in the genomics era. Nat. Rev. Drug Discov. 2015, 14, 111-129. [CrossRef]

36. Chin, Y.-W.; Balunas, M.J.; Chai, H.B.; Kinghorn, A.D. Drug discovery from natural sources. AAPS J. 2006, 8, E239-E253. [CrossRef]

37. Schmidt, T.; Khalid, S.; Romanha, A.; Alves, T.; Biavatti, M.; Brun, R.; Da Costa, F.; De Castro, S.; Ferreira, V.; De Lacerda, M.; et al. The Potential of Secondary Metabolites from Plants as Drugs or Leads Against Protozoan Neglected Diseases - Part II. Curr. Med. Chem. 2012, 19, 2176-2228. [CrossRef]

38. Newman, D.J.; Cragg, G.M. Natural Products as Sources of New Drugs from 1981 to 2014. J. Nat. Prod. 2016, 79, 629-661. [CrossRef] [PubMed]

39. Houghton, P.J.; Osibogun, I.M. Flowering plants used against snakebite. J. Ethnopharmacol. 1993, 39, 1-29. [CrossRef]

40. Gomes, A.; Das, R.; Sarkhel, S.; Mishra, R.; Mukherjee, S.; Bhattacharya, S.; Gomes, A. Herbs and herbal constituents active against snakebite. Indian J. Exp. Biol. 2010, 48, 865-878. [PubMed]

41. Castro, O.; Gutiérrez, J.M.; Barrios, M.; Castro, I.; Romero, M.; Umaña, E. Neutralization of the hemorrhagic effect induced by Bothrops asper (Serpentes: Viperidae) venom with tropical plant extracts. Revista de Biología Tropical 1999, 47, 605-616. [PubMed]

42. Melo, P.A.; Nascimento, M.C.D.; Mors, W.B.; Suarez-Kurtz, G. Inhibition of the myotoxic and hemorrhagic activities of crotalid venoms by Eclipta prostrata (Asteraceae) extracts and constituents. Toxicon 1994, 32, 595-603. [CrossRef]

43. Mors, W.B.; Nascimento, M.C.D.; Parente, J.; Da Silva, M.H.; Melo, P.A.; Suarez-Kurtz, G. Neutralization of lethal and myotoxic activities of South American rattlesnake venom by extracts and constituents of the plant Eclipta prostrata (Asteraceae). Toxicon 1989, 27, 1003-1009. [CrossRef]

44. Núñez, V.; Castro, V.; Murillo, R.; Ponce-Soto, L.A.; Merfort, I.; Lomonte, B. Inhibitory effects of Piper umbellatum and Piper peltatum extracts towards myotoxic phospholipases A2 from Bothrops snake venoms: Isolation of 4-nerolidylcatechol as active principle. Phytochemistry 2005, 66, 1017-1025. [CrossRef] [PubMed]

45. Reyes-Chilpa, R.; Gómez-Garibay, F.; Quijano, L.; Magos-Guerrero, G.A.; Rios, T. Preliminary results on the protective effect of (-)-edunol, a pterocarpan from Brongniartia podalyrioides (Leguminosae), against Bothrops atrox venom in mice. J. Ethnopharmacol. 1994, 42, 199-203. [CrossRef]

46. Amui, S.F.; Puga, R.D.; Soares, A.M.; Giuliatti, S. Plant-antivenom: Database of anti-venom medicinal plants. Eletronic, J. Biotechnol 2010, 14, 6-7. [CrossRef]

47. Chandrashekara, K.T.; Nagaraju, S.; Nandini, S.U.; Kemparaju, K. Neutralization of local and systemic toxicity of Daboia russelli venom by Morus alba plant leaf extract. Phytother. Res. 2009, 23, 1082-1087. [CrossRef]

48. Fung, S.Y.; Tan, N.H.; Liew, S.H.; Sim, S.M.; Aguiyi, J.C. The protective effects of Mucuna pruriens seed extract against histopathological changes induced by Malayan cobra (Naja sputatrix) venom in rats. Trop. Biomed. 2009, 26, 80-84.

49. Tan, N.H.; Fung, S.Y.; Sim, S.M.; Marinello, E.; Guerranti, R.; Aguiyi, J.C. The protective effect of Mucuna pruriens seeds against snake venom poisoning. J. Ethnopharmacol. 2009, 123, 356-358. [CrossRef] [PubMed]

50. Scirè, A.; Tanfani, F.; Bertoli, E.; Furlani, E.; Nadozie, H.-O.N.; Cerutti, H.; Cortelazzo, A.; Bini, L.; Guerranti, R. The belonging of gpMuc, a glycoprotein from Mucuna pruriens seeds, to the Kunitz-type trypsin inhibitor family explains its direct anti-snake venom activity. Phytomedicine 2011, 18, 887-895. [CrossRef]

51. Hasson, S.S.; Al-Jabri, A.A.; Sallam, T.A.; Al-Balushi, M.S.; Mothana, R.A.A. Antisnake Venom Activity of Hibiscus aethiopicus L. against Echis ocellatus and Naja nigricollis. J. Toxicol. 2010, 2010, 1-8. [CrossRef] [PubMed]

52. Mahadeswaraswamy, Y.H.; Devaraja, S.; Kumar, M.S.; Goutham, Y.N.J.; Kemparaju, K. Inhibition of local effects of Indian Daboia/Vipera russelli venom by the methanolic extract of grape (Vitis vinifera L.) seeds. Indian J. Biochem. Biophys. 2009, 46, 154-160. [PubMed] 
53. Nazato, V.S.; Rubem-Mauro, L.; Vieira, N.A.G.; Rocha-Junior, D.D.S.; Silva, M.G.; Lopes, P.S.; Dal-Belo, C.A.; Cogo, J.C.; Dos Santos, M.G.; Da Cruz-Höfling, M.A.; et al. In Vitro Antiophidian Properties of Dipteryx alata Vogel Bark Extracts. Molecules 2010, 15, 5959-5970. [CrossRef] [PubMed]

54. Puebla, P.; Oshima-Franco, Y.; Franco, L.M.; Dos Santos, M.G.; Da Silva, R.V.; Rubem-Mauro, L.; Feliciano, A.S. Chemical Constituents of the Bark of Dipteryx alata Vogel, an Active Species against Bothrops jararacussu Venom. Molecules 2010, 15, 8193-8204. [CrossRef]

55. Magalhães, A.; Dos Santos, G.B.; Verdam, M.C.D.S.; Fraporti, L.; Malheiro, A.; Lima, E.S.; Dos-Santos, M.C. Inhibition of the inflammatory and coagulant action of Bothrops atrox venom by the plant species Marsypianthes chamaedrys. J. Ethnopharmacol. 2011, 134, 82-88. [CrossRef]

56. Assafim, M.; De Coriolano, E.C.; Benedito, S.E.; Fernandes, C.P.; Lobo, J.F.R.; Sanchez, E.F.; Rocha, L.M.; Fuly, A.L. Hypericum brasiliense plant extract neutralizes some biological effects of Bothrops jararaca snake venom. J. Ven. Res. 2011, 2, 11-16.

57. A Ibrahim, M.; Aliyu, A.B.; Abusufiyanu, A.; Bashir, M.; Sallau, A.B. Inhibition of Naja nigricolis (Reinhardt) venom protease activity by Luffa egyptiaca (Mill) and Nicotiana rustica (Linn) extracts. Indian J. Exp. Biol. 2011, 49, 552-554.

58. Dhananjaya, B.L.; Zameer, F.; Girish, K.S.; D'Souza, C.J.M. Anti-venom potential of aqueous extract of stem bark of Mangifera indica L. against Daboia russellii (Russell's viper) venom. Indian J. Biochem. Biophys. 2011, 48, 175-183. [PubMed]

59. Torres, A.M.; Camargo, F.J.; Ricciardi, G.A.L.; Ricciardi, A.I.A.; Dellacassa, E. Neutralizing effects of Nectandra angustifolia extracts against Bothrops neuwiedi snake venom. Nat. Prod. Commun. 2011, 6, 1393-1396. [CrossRef] [PubMed]

60. Razi, M.T.; Asad, M.H.; Khan, T.; Zabta Chaudhary, M.; Tayyab Ansari, M.; Arshad, M.A.; Saqib, Q.N.U. Antihaemorrhagic potentials of Fagonia cretica against Naja naja karachiensis (Black Pakistan cobra) venom. Nat. Prod. Res. 2011, 25, 1902-1907. [CrossRef] [PubMed]

61. da Silva, M.L.; Marcussi, S.; Fernandes, R.S.; Pereira, P.S.; Januário, A.H.; França, S.C.; Da Silva, S.L.; Soares, A.M.; Lourenço, M.V. Anti-snake venom activities of extracts and fractions from callus cultures of Sapindus saponaria. Pharmacol. Biol. 2012, 50, 366-375. [CrossRef] [PubMed]

62. Nishijima, C.M.; Rodrigues, C.M.; Silva, M.A.; Lopes-Ferreira, M.; Vilegas, W.; Hiruma-Lima, C.A. Anti-hemorrhagic Activity of Four Brazilian Vegetable Species Against Bothrops jararaca Venom. Molecules 2009, 14, 1072-1080. [CrossRef] [PubMed]

63. Ushanandini, S.; Nagaraju, S.; Nayaka, S.C.; Kumar, K.H.; Kemparaju, K.; Girish, K.S. The anti-ophidian properties of Anacardium occidentale bark extract. Immunopharmacol. Immunotoxicol. 2009, 31, 607-615. [CrossRef] [PubMed]

64. Ushanandini, S.; Nagaraju, S.; Kumar, K.H.; Vedavathi, M.; Machiah, D.K.; Kemparaju, K.; Vishwanath, B.S.; Gowda, T.V.; Girish, K.S. The anti-snake venom properties of Tamarindus indica (leguminosae) seed extract. Phytotherapy Res. 2006, 20, 851-858. [CrossRef] [PubMed]

65. Rizzini, C.T.; Mors, W.B.; Pereira, N.A. Plantas brasileiras tidas como ativas contra peçonhas de animais, especialmente veneno de cobra. Rev. Bras. Farmacog 1988, 69, 5.

66. Mors, W.B. Plants against snake-bites. Memorias do Instituto Oswaldo Cruz 1991, 86 (Suppl. 2), 193. [CrossRef]

67. Martz, W. Plants with a reputation against snakebite. Toxicon 1992, 30, 1131-1142. [CrossRef]

68. Otero, R.; Fonnegra, R.; Jiménez, S.L.; Núñez, V.; Evans, N.; Alzate, S.P.; E García, M.; Saldarriaga, M.; Del Valle, G.; Osorio, R.G.; et al. Snakebites and ethnobotany in the northwest region of Colombia: Part I: Traditional use of plants. J. Ethnopharmacol. 2000, 71, 493-504. [CrossRef]

69. Soares, A.; Januario, A.; Lourenço, M.; Pereira, A.; Pereira, P.S. Neutralizing effects of Brazilian plants against snake venoms. Drugs Futur. 2004, 29, 1105. [CrossRef]

70. Lomonte, B.; León, G.; Angulo, Y.; Rucavado, A.; Núñez, V. Neutralization of Bothrops asper venom by antibodies, natural products and synthetic drugs: Contributions to understanding snakebite envenomings and their treatment. Toxicon 2009, 54, 1012-1028. [CrossRef] [PubMed]

71. Tusha.; Basak, S.; Sarma, G.C.; Rangan, L. Ethnomedical uses of Zingiberaceous plants of Northeast India. J. Ethnopharmacol. 2010, 132, 286-296. [CrossRef] [PubMed]

72. Molander, M.; Saslis-Lagoudakis, C.H.; Jäger, A.K.; Rønsted, N. Cross-cultural comparison of medicinal floras used against snakebites. J. Ethnopharmacol. 2012, 139, 863-872. [CrossRef] [PubMed] 
73. Dey, A.; Nath De, N. Phytopharmacology of antiophidian botanicals. Inter. J. Pharmacol. 2012, 8, 18. [CrossRef]

74. Houghton, P.J.; Skari, K.P. The effect on blood clotting of some west African plants used against snakebite. J. Ethnopharmacol. 1994, 44, 99-108. [CrossRef]

75. Molander, M.; Nielsen, L.; Sogaard, S.; Staerk, D.; Rønsted, N.; Diallo, D.; Chifundera, K.Z.; van Staden, J.; Jäger, A.K. Hyaluronidase, Phospholipase A2 and protease inhibitory activity of plants used in traditional treatments of snake-induced tissue necrosis in Mali, DR Congo and South Africa. J. Ethnopharmacol. 2014, 157, 171-180. [CrossRef]

76. Vale, L.H.F.; Mendes, M.M.; Hamaguchi, A.; Rodrigues, V.M.; Homsi-Brandeburgo, M.I.; Soares, A.M. Neutralization of Pharmacological and Toxic Activities of Bothrops Snake Venoms by Schizolobium parahyba (Fabaceae) Aqueous Extract and Its Fractions. Basic Clin. Pharmacol. Toxicol. 2008, 103, 104-107. [CrossRef]

77. Hung, Y.-C.; Sava, V.; Hong, M.-Y.; Huang, G. Inhibitory effects on phospholipase A2 and antivenin activity of melanin extracted from Thea sinensis Linn. Life Sci. 2004, 74, 2037-2047. [CrossRef]

78. Alam, M.I.; Gomes, A. Adjuvant effects and antiserum action potentiation by a (herbal) compound 2-hydroxy-4-methoxy benzoic acid isolated from the root extract of the Indian medicinal plant "sarsaparilla" (Hemidesmus indicus R. Br.). Toxicon 1998, 36, 1423-1431. [CrossRef]

79. Chatterjee, I.; Chakravarty, A.; Gomes, A. Daboia russellii and Naja kaouthia venom neutralization by lupeol acetate isolated from the root extract of Indian sarsaparilla Hemidesmus indicus R.Br. J. Ethnopharmacol. 2006, 106, 38-43. [CrossRef] [PubMed]

80. Gupta, Y.K.; Peshin, S.S. Snake bite in India: Current scenario of an old problem. J. Clin. Toxicol. 2014, 4, 1-9. [CrossRef]

81. Gómez-Betancur, I.; Pereañez, J.A.; Patiño, A.C.; Benjumea, D. Inhibitory effect of pinostrobin from Renealmia alpinia, on the enzymatic and biological activities of a PLA2. Int. J. Biol. Macromol. 2016, 89, 35-42. [CrossRef] [PubMed]

82. Santhosh, M.S.; Hemshekhar, M.; Sunitha, K.; Thushara, R.M.; Jnaneshwari, S.; Kemparaju, K.; Girish, K.S. Snake Venom Induced Local Toxicities: Plant Secondary Metabolites as an Auxiliary Therapy. Mini-Reviews Med. Chem. 2013, 13, 106-123. [CrossRef]

83. Leanpolchareanchai, J.; Pithayanukul, P.; Bavovada, R.; Saparpakorn, P. Molecular Docking Studies and Anti-enzymatic Activities of Thai Mango Seed Kernel Extract Against Snake Venoms. Molecules 2009, 14, 1404-1422. [CrossRef] [PubMed]

84. Toyama, D.; Marangoni, S.; Diz-Filho, E.; Oliveira, S.; Toyama, M. Effect of umbelliferone (7-hydroxycoumarin, 7-HOC) on the enzymatic, edematogenic and necrotic activities of secretory phospholipase A2 (sPLA2) isolated from Crotalus durissus collilineatus venom. Toxicon 2009, 53, 417-426. [CrossRef]

85. Mors, W.B.; Nascimento, M.C.D.; Pereira, B.M.R.; Pereira, N.A. Plant natural products active against snake bite - the molecular approach. Phytochemistry 2000, 55, 627-642. [CrossRef]

86. Singh, N.; Jabeen, T.; Sharma, S.; Perbandt, M.; Betzel, C.; Singh, T.P. Crystal structures of the complexes of a group IIA phospholipase A2 with two natural anti-inflammatory agents, anisic acid, and atropine reveal a similar mode of binding. Proteins 2016, 64, 89-100. [CrossRef] [PubMed]

87. Soares, A.M.; Ticli, F.K.; Marcussi, S.; Lourenço, M.V.; Januário, A.H.; Sampaio, S.V.; Giglio, J.R.; Lomonte, B.; Pereira, P.S. Medicinal plants with inhibitory properties against snake venoms. Curr. Med. Chem. 2005, 12, 2625-2641. [CrossRef]

88. Jiménez-Estrada, M.; Velázquez-Contreras, C.; Garibay-Escobar, A.; Sierras-Canchola, D.; Lapizco-Vázquez, R.; Ortiz-Sandoval, C.; Burgos-Hernández, A.; Robles-Zepeda, R.E. In vitro antioxidant and antiproliferative activities of plants of the ethnopharmacopeia from northwest of Mexico. BMC Complement. Altern. Med. 2013, 13, 12. [CrossRef] [PubMed]

89. Gupta, Y.K.; Peshin, S.S. Do herbal medicines have potential for managing snake bite envenomation? Toxicol. Int. 2012, 19, 89. [CrossRef] [PubMed]

90. Molander, M.; Staerk, D.; Nielsen, H.M.; Brandner, J.N.; Diallo, D.; Zacharie, C.K.; van Staden, J.; Jäger, A.K. Investigation of skin permeation, ex vivo inhibition of venom-induced tissue destruction, and wound healing of African plants used against snakebites. J. Etnopharmacol. 2015, 165, 1-8. [CrossRef] [PubMed]

91. Aboul-Enein, H.Y.; Kruk, I.; Kładna, A.; Lichszteld, K.; Michalska, T. Scavenging effects of phenolic compounds on reactive oxygen species. Biopolymers 2007, 86, 222-230. [CrossRef] [PubMed] 
92. Rohn, S.; Rawel, H.M.; Kröll, J. Inhibitory Effects of Plant Phenols on the Activity of Selected Enzymes. J. Agric. Food Chem. 2002, 50, 3566-3571. [CrossRef] [PubMed]

93. Alam, M.I.; Alam, M.A.; Alam, O.; Nargotra, A.; Taneja, S.C.; Koul, S. Molecular modeling and snake venom phospholipase A 2 inhibition by phenolic compounds: Structure-activity relationship. Eur. J. Med. Chem. 2016, 114, 209-219. [CrossRef] [PubMed]

94. Nargotra, A.; Sharma, S.; Alam, M.I.; Ahmed, Z.; Bhagat, A.; Taneja, S.C.; Qazi, G.N.; Koul, S. In silico identification of viper phospholipaseA2 inhibitors: Validation by in vitro, in vivo studies. J. Mol. Model. 2011, 17, 3063-3073. [CrossRef] [PubMed]

95. Pereañez, J.A.; Núñez, V.; Patiño, A.C.; Londono, M.; Quintana, J.C. Inhibitory effects of plants phenolic compounds on enzymatic and cytotoxic activities induced by a snake venom phospholipase A2. Vitae 2011, 18, 295-304.

96. Das, K. Medicinal plants for snake bite treatment - Future focus. Ethnobot. Leaf 2009, 13, 14.

97. Vishwanath, B.; Rao, A.A.; Gowda, T. Interaction of phospholipase A2 from Vipera russelli venom with aristolochic acid: A circular dichroism study. Toxicon 1987, 25, 939-946. [CrossRef]

98. Chandra, V.; Jasti, J.; Kaur, P.; Srinivasan, A.; Betzel, C.; Singh, T.P. Structural Basis of Phospholipase A2 Inhibition for the Synthesis of Prostaglandins by the Plant Alkaloid Aristolochic Acid from a $1.7 \AA$ Crystal Structure. Biochemistry 2002, 41, 10914-10919. [CrossRef] [PubMed]

99. Girish, K.S.; Kemparaju, K. Inhibition of Naja naja venom hyaluronidase by plant-derived bioactive components and polysaccharides. Biochemistry (Moscow) 2005, 70, 948-952. [CrossRef]

100. Kemparaju, K.; Girish, K.S. Snake venom hyaluronidase: A therapeutic target. Cell Biochem. Funct. 2006, 24, 7-12. [CrossRef] [PubMed]

101. Xiao, J. Dietary flavonoid aglycones and their glycosides: ¿Which show better biological significance? Crit. Rev. Food Sci. Nutr. 2017, 57, 1874-1905. [CrossRef] [PubMed]

102. Kuppusamy, U.R.; Das, N.P. Inhibitory effects of flavonoids on several venom hyaluronidases. Cell. Mol. Life Sci. 1991, 47, 1196-1200. [CrossRef] [PubMed]

103. Gómez-Betancur, I.; Benjumea, D.; Patiño, A.; Jimenez, N.; Osorio, E. Inhibition of the toxic effects of Bothrops asper venom by pinostrobin, a flavanone isolated from Renealmia alpinia (Rottb.) MAAS. J. Ethnopharmacol. 2014, 155, 1609-1615. [CrossRef] [PubMed]

104. Preciado, L.M.; Comer, J.; Núñez, V.; Rey-Súarez, P.; Pereañez, J.A. Inhibition of a Snake Venom Metalloproteinase by the Flavonoid Myricetin. Molecules 2018, 23, 2662. [CrossRef] [PubMed]

105. Gopi, K.; Anbarasu, K.; Renu, K.; Jayanthi, S.; Vishwanath, B.; Jayaraman, G. Quercetin-3-O-rhamnoside from Euphorbia hirta protects against snake Venom induced toxicity. Biochim. Biophys. Acta (BBA) - Gen. Subj. 2016, 1860, 1528-1540. [CrossRef] [PubMed]

106. Sachetto, A.T.A.; Rosa, J.G.; Santoro, M.L. Rutin (quercetin-3-rutinoside) modulates the hemostatic disturbances and redox imbalance induced by Bothrops jararaca snake venom in mice. PLoS Neglected Trop. Dis. 2018, 12, e0006774. [CrossRef]

107. Nakagawa, M.; Nakanishi, K.; Darko, L.L.; Vick, J.A. Structures of cabenegrins A-I and A-II, potent anti-snake venoms. Tetrahedron Lett. 1982, 23, 3855-3858. [CrossRef]

108. Ximenes, R.M.; Alves, R.S.; Pereira, T.P.; Araújo, R.M.; Silveira, E.R.; Rabello, M.M.; Hernandes, M.Z.; Soares, V.C.G.; Bristot, D.; Pires, C.L.; et al. Harpalycin 2 inhibits the enzymatic and platelet aggregation activities of PrTX-III, a D49 phospholipase A2 from Bothrops pirajai venom. BMC Complement. Altern. Med. 2012, 12, 139. [CrossRef] [PubMed]

109. Gershenzon, J.; Dudareva, N. The function of terpene natural products in the natural world. Nat. Methods 2007, 3, 408-414. [CrossRef] [PubMed]

110. Domingos, T.F.S.; Vallim, M.A.; Cavalcanti, D.N.; Sanchez, E.F.; Teixeira, V.L.; Fuly, A.L. Effect of Diterpenes Isolated of the Marine Alga Canistrocarpus cervicornis against Some Toxic Effects of the Venom of the Bothrops jararaca Snake. Molecules 2015, 20, 3515-3526. [CrossRef] [PubMed]

111. Muthusamy, K.; Chinnasamy, S.; Nagarajan, S.; Sivaraman, T.; Chinnasamy, S. Isolation and characterization of bioactive compounds of Clematis gouriana Roxb. ex DC against snake venom phospholipase A2 (PLA2) computational and in vitro insights. J. Biomol. Struct. Dyn. 2017, 35, 1936-1949. [CrossRef] [PubMed]

112. Da Silva, J.O.; Fernandes, R.S.; Ticli, F.K.; Oliveira, C.Z.; Mazzi, M.V.; Franco, J.J.; Giuliatti, S.; Pereira, P.S.; Soares, A.M.; Sampaio, S.V. Triterpenoid saponins, new metalloprotease snake venom inhibitors isolated from Pentaclethra macroloba. Toxicon 2007, 50, 283-291. [CrossRef] [PubMed] 
113. Preciado, L.M.; Rey-Suárez, P.; Henao, I.C.; Pereañez, J.A. Betulinic, oleanolic and ursolic acids inhibit the enzymatic and biological effects induced by a P-I snake venom metalloproteinase. Chem. Interactions 2018, 279, 219-226. [CrossRef] [PubMed]

114. Moura, L.D.A.; Sanchez, E.F.; Bianco, É.M.; Pereira, R.C.; Teixeira, V.L.; Fuly, A.L. Antiophidian properties of a dolastane diterpene isolated from the marine brown alga Canistrocarpus cervicornis. Biomed. Prev. Nutrit. 2011, 1, 61-66. [CrossRef]

115. Dharmappa, K.K.; Kumar, R.V.; Nataraju, A.; Pereira, R.C.; Teixeira, V.L.; Fuly, A.L. Anti-inflammatory activity of oleanolic acid by inhibition of secretory phospholipase A2. Planta Med. 2009, 75, 211-215. [CrossRef]

116. Batina, M.D.F.C.; Cintra, A.C.O.; Veronese, E.L.G.; Lavrador, M.A.S.; Giglio, J.R.; Pereira, P.S.; Dias, D.A.; França, S.C.; Sampaio, S.V. Inhibition of the Lethal and Myotoxic Activities of Crotalus durissus terrificus Venom by Tabernaemontana catharinensis: Identification of One of the Active Components. Planta Med. 2000, 66, 424-428. [CrossRef]

117. Menecucci, C.D.S.; Mucellini, K.L.; De Oliveira, M.M.; Higashi, B.; De Almeida, R.T.R.; Porto, C.; Pilau, E.J.; Gonçalves, J.E.; Gonçalves, R.A.C.; De Oliveira, A.J.B. Latex from Tabernaemontana catharinensis (A. DC)-Apocynaceae: An alternative for the sustainable production of biologically active compounds. Ind. Crop. Prod. 2019, 129, 74-84. [CrossRef]

118. Samy, R.P.; Gopalakrishnakone, P.; Chow, V.T. Therapeutic application of natural inhibitors against snake venom phospholipase A2. Bioinformation 2012, 8, 48-57. [CrossRef] [PubMed]

119. Bhattacharjee, P.; Bhattacharyya, D. Characterization of the aqueous extract of the root of Aristolochia indica: Evaluation of its traditional use as an antidote for snake bites. J. Ethnopharmacol. 2013, 145, 220-226. [CrossRef] [PubMed]

120. Bhattacharjee, P.; Bera, I.; Chakraborty, S.; Ghoshal, N.; Bhattacharyya, D. Aristolochic acid and its derivatives as inhibitors of snake venom $\mathrm{L}$-amino acid oxidase. Toxicon 2017, 138, 1-17. [CrossRef] [PubMed]

121. Fernandes, C.A.H.; Cardoso, F.F.; Cavalcante, W.G.L.; Soares, A.M.; Dal-Pai, M.; Gallacci, M.; Fontes, M.R.M. Structural Basis for the Inhibition of a Phospholipase A2-Like Toxin by Caffeic and Aristolochic Acids. PLoS ONE 2015, 10, e0133370. [CrossRef] [PubMed]

122. Ticli, F.K.; Hage, L.I.; Cambraia, R.S.; Pereira, P.S.; Magro, A.J.; Fontes, M.R.; Stabeli, R.G.; Giglio, J.R.; França, S.C.; Soares, A.M.; et al. Rosmarinic acid, a new snake venom phospholipase A2 inhibitor from Cordia verbenacea (Boraginaceae): Antiserum action potentiation and molecular interaction. Toxicon 2005, 46, 318-327. [CrossRef] [PubMed]

123. DosSantos, J.I.; Cardoso, F.F.; Soares, A.M.; dal Pai Silva, M.; Gallacci, M.; Fontes, M.R.M. Structural and functional studies of a bothropic myotoxin complexed to rosmarinic acid: New insights into Lys49-PLA 2 inhibition. PLoS ONE 2011, 6, e28521.

124. Aung, H.T.; Nikai, T.; Niwa, M.; Takaya, Y. Rosmarinic acid in Argusia argentea inhibits snake venom-induced hemorrhage. J. Nat. Med. 2010, 64, 482-486. [CrossRef]

125. Aung, H.T.; Furukawa, T.; Nikai, T.; Niwa, M.; Takaya, Y. Contribution of cinnamic acid analogues in rosmarinic acid to inhibition of snake venom induced hemorrhage. Bioorganic Med. Chem. 2011, 19, 2392-2396. [CrossRef]

126. Gopi, K.; Renu, K.; Vishwanath, B.S.; Jayaraman, G. Protective effect of Euphorbia hirta and its components against snake venom induced lethality. J. Ethnopharmacol. 2015, 165, 180-190. [CrossRef]

127. Mukherjee, A.K.; Doley, R.; Saikia, D. Isolation of a snake venom phospholipase A2 (PLA2) inhibitor (AIPLAI) from leaves of Azadirachta indica (Neem): Mechanism of PLA2 inhibition by AIPLAI in vitro condition. Toxicon 2008, 51, 1548-1553. [CrossRef]

128. Alam, M.I.; Auddy, B.; Gomes, A. Viper venom neutralization by Indian medicinal plant (Hemidesmus indicus and Pluchea indica) root extracts. Phytother. Res. 1996, 10, 58-61. [CrossRef]

129. Tomaz, M.A.; Patrão-Neto, F.C.; Melo, P.A.; Gopalakrishnakone, P.; Carlini, C.R.; Ligabue-Braun, R. Plant Compounds with Antiophidic Activities, Their Discovery History, and Current and Proposed Applications. Toxinology 2016, 1-16. [CrossRef]

130. Strauch, M.A.; Tomaz, M.A.; Monteiro-Machado, M.; Ricardo, H.D.; Cons, B.L.; Fernandes, F.F.; El-Kik, C.Z.; Azevedo, M.S.; Melo, P.A. Antiophidic activity of the extract of the Amazon plant Humirianthera ampla and constituents. J. Ethnopharmacol. 2013, 145, 50-58. [CrossRef] [PubMed] 
131. Xiong, Y.; Li, B.; Huang, D.; He, Q.; Yu, X. Anti- Deinagkistrodon acutus venom properties of ethanolic root extract from Cynanchum paniculatum (Bunge) kitag and its GC-MS analysis. J. Ethnopharmacol. 2018, 225, 189-197. [CrossRef] [PubMed]

132. Melo, P.A.; Pinheiro, D.A.; Ricardo, H.D.; Fernandes, F.F.; Tomaz, M.A.; El-Kik, C.Z.; Strauch, M.A.; Da Fonseca, T.F.; Sifuentes, D.N.; Calil-Eliás, S.; et al. Ability of a synthetic coumestan to antagonize Bothrops snake venom activities. Toxicon 2010, 55, 488-496. [CrossRef] [PubMed]

133. Januário, A.H.; Santos, S.L.; Marcussi, S.; Mazzi, M.V.; Pietro, R.C.; Sato, D.N.; Ellena, J.; Sampaio, S.V.; França, S.C.; Soares, A.M. Neo-clerodane diterpenoid, a new metalloprotease snake venom inhibitor from Baccharis trimera (Asteraceae): Anti-proteolytic and anti-hemorrhagic properties. Chem. Interactions 2004, 150, 243-251. [CrossRef] [PubMed]

134. Da Silva, S.L.; Calgarotto, A.K.; Chaar, J.S.; Marangoni, S. Isolation and characterization of ellagic acid derivatives isolated from Casearia sylvestris SW aqueous extract with anti-PLA2 activity. Toxicon 2008, 52, 655-666. [CrossRef] [PubMed]

135. Esteves, I.; Lima, L.M.; Santos, L.S.; Rodrigues, M.; da Silva, J.M.S.; Perazzo, F.F.; Carvalho, J.C.T. Casearia sylvestris SW essential oil activity in inflammation in rats induced by Bothrops alternatus venom. Int. J. Pharm. Sci. Rev. Res. 2011, 7, 5.

136. Ode, O.; Asuzu, I. The anti-snake venom activities of the methanolic extract of the bulb of Crinum jagus (Amaryllidaceae). Toxicon 2006, 48, 331-342. [CrossRef]

137. Shukla, P.K.; Gautam, L.; Sinha, M.; Kaur, P.; Sharma, S.; Singh, T.P. Structures and binding studies of the complexes of phospholipase A2 with five inhibitors. Biochim. Biophys. Acta (BBA) - Proteins Proteom. 2015, 1854, 269-277. [CrossRef]

138. Esmeraldino, L.E.; Souza, A.M.; Sampaio, S.V. Evaluation of the effect of aqueous extract of Croton urucurana Bailon (Euphorbiaceae) on the hemorrhagic activity induced by the venom of Bothrops jararaca, using new techniques to quantify hemorrhagic activity in rat skin. Phytomedicine 2005, 12, 570-576. [CrossRef] [PubMed]

139. Passos, G.F.; Fernandes, E.S.; Da Cunha, F.M.; Ferreira, J.; Pianowski, L.F.; Campos, M.M.; Calixto, J.B. Anti-inflammatory and anti-allergic properties of the essential oil and active compounds from Cordia verbenacea. J. Ethnopharmacol. 2007, 110, 323-333. [CrossRef] [PubMed]

140. Fernandes, E.S.; Passos, G.F.; Medeiros, R.; Da Cunha, F.M.; Ferreira, J.; Campos, M.M.; Pianowski, L.F.; Calixto, J.B. Anti-inflammatory effects of compounds alpha-humulene and (-)-trans-caryophyllene isolated from the essential oil of Cordia verbenacea. Eur. J. Pharmacol. 2007, 569, 228-236. [CrossRef] [PubMed]

141. Azofeifa, K.; Angulo, Y.; Lomonte, B. Ability of fucoidan to prevent muscle necrosis induced by snake venom myotoxins: Comparison of high- and low-molecular weight fractions. Toxicon 2008, 51, 373-380. [CrossRef] [PubMed]

142. Wagner, H.; Geyer, B.; Kiso, Y.; Hikino, H.; Rao, G. Coumestans as the Main Active Principles of the Liver Drugs Eclipta alba and Wedelia calendulacea. Planta Med. 1986, 52, 370-374. [CrossRef]

143. Saxena, A.; Singh, B.; Anand, K. Hepatoprotective effects of Eclipta alba on subcellular levels in rats. J. Ethnopharmacol. 1993, 40, 155-161. [CrossRef]

144. Diogo, L.C.; Fernandes, R.S.; Marcussi, S.; Menaldo, D.L.; Roberto, P.G.; Matrangulo, P.V.F.; Pereira, P.S.; França, S.C.; Giuliatti, S.; Soares, A.M.; et al. Inhibition of Snake Venoms and Phospholipases A2 by Extracts from Native and Genetically Modified Eclipta alba: Isolation of Active Coumestans. Basic Clin. Pharmacol. Toxicol. 2009, 104, 293-299. [CrossRef] [PubMed]

145. Pithayanukul, P.; Laovachirasuwan, S.; Bavovada, R.; Pakmanee, N.; Suttisri, R. Anti-venom potential of butanolic extract of Eclipta prostrata against Malayan pit viper venom. J. Ethnopharmacol. 2004, 90, 347-352. [CrossRef]

146. Alam, M.; Auddy, B.; Gomes, A. Isolation, purification and partial characterization of viper venom inhibiting factor from the root extract of the Indian medicinal plant sarsaparilla (Hemidesmus indicus R.Br.). Toxicon 1994, 32, 1551-1557. [CrossRef]

147. Borges, M.; Alves, D.; Raslan, D.; Piló-Veloso, D.; Rodrigues, V.; Homsi-Brandeburgo, M.; De Lima, M. Neutralizing properties of Musa paradisiaca L. (Musaceae) juice on phospholipase A2, myotoxic, hemorrhagic and lethal activities of crotalidae venoms. J. Ethnopharmacol. 2005, 98, 21-29. [CrossRef]

148. Min, H.M.; Aye, M.; Taniguchi, T.; Miura, N.; Monde, K.; Ohzawa, K.; Nikai, T.; Niwa, M.; Takaya, Y. A structure and an absolute configuration of (+)-alternamin, a new coumarin from Murraya alternans having antidote activity against snake venom. Tetrahedron Lett. 2007, 48, 6155-6158. [CrossRef] 
149. Torres, M.C.M.; Pinto, F.D.C.L.; Filho, R.B.; Silveira, E.R.; Pessoa, O.D.L.; Jorge, R.J.B.; Ximenes, R.M.; Monteiro, H.S.A.; Evangelista, J.S.A.M.; Diz-Filho, E.B.S.; et al. Antiophidic Solanidane Steroidal Alkaloids from Solanum campaniforme. J. Nat. Prod. 2011, 74, 2168-2173. [CrossRef] [PubMed]

150. Machiah, D.K.; Girish, K.; Gowda, T.V. A glycoprotein from a folk medicinal plant, Withania somnifera, inhibits hyaluronidase activity of snake venoms. Comp. Biochem. Physiol. Part C Toxicol. Pharmacol. 2006, 143, 158-161. [CrossRef] [PubMed]

151. Ribeiro, A.E.A.S.; Soares, J.M.D.; Silva, H.A.L.; de Souza Wanderley, C.W.; Moura, C.A.; de Oliveira-Junior, R.G.; de Oliveira, A.P.; Rolim, L.A.; Costa, E.V.; da Silva Almeida, J.R.G.; et al. Inhibitory effects of Morus nigra L. (Moraceae) against local paw edema and mechanical hypernociception induced by Bothrops jararacussu snake venom in mice. Biomed Pharmacother. 2019, 111, 1046-4056. [CrossRef] [PubMed]

152. Toyama, M.H.; Toyama, D.O.; Torres, V.M.; Pontes, G.C.; Farias, W.R.L.; Melo, F.R.; Oliveira, S.C.B.; Fagundes, F.H.R.; Diz Filho, E.B.S.; Cavada, B.S. Effects of low molecular weight sulfated galactan fragments from Botryocladia occidentalis on the pharmacological and enzymatic activity of sPLA2 from Crotalus durissus cascavella. Protein J. 2010, 29, 567-571. [CrossRef] [PubMed]

153. Bennett, C.; Mong, S.; Clarke, M.A.; Kruse, L.I.; Crooke, S.T. Differential effects of manoalide on secreted and intracellular phospholipases. Biochem. Pharmacol. 1987, 36, 733-740. [CrossRef]

154. Rocha, S.L.G.; Lomonte, B.; Neves-Ferreira, A.G.C.; Trugilho, M.R.O.; Junqueira-De-Azevedo, I.D.L.M.; Ho, P.L.; Domont, G.B.; Gutiérrez, J.M.; Perales, J.; Neves-Ferreira, A.G.C.; et al. Functional analysis of DM64, an antimyotoxic protein with immunoglobulin-like structure from Didelphis marsupialis serum. Eur. J. Biochem. 2002, 269, 6052-6062. [CrossRef]

155. Pan, S.Y.; Chen, S.B.; Dong, H.G.; Yu, Z.L.; Dong, J.C.; Long, Z.X.; Fong, W.F.; Han, Y.F.; Ko, K.M. New perspectives on Chinese herbal medicine (Zhong-Yao) research and development. Evid-Based Complement. Alternat. Med. 2011, 403709. [CrossRef]

156. Poupko, J.M.; Baskin, S.I.; Moore, E. The pharmacological properties of anisodamine. J. Appl. Toxicol. 2007, 27, 116-121. [CrossRef]

157. Eisenbrand, G.; Hippe, F.; Jakobs, S.; Muehlbeyer, S. Molecular mechanisms of indirubin and its derivatives: Novel anticancer molecules with their origin in traditional Chinese phytomedicine. J. Cancer Res. Clin. Oncol. 2004, 130, 627-635. [CrossRef]

158. Desilets, A.R.; Gickas, J.J.; Dunican, K.C. Role of huperzine A in the treatment of Alzheimer's disease. Ann. Pharmacother. 2009, 43, 514-518. [CrossRef] [PubMed]

159. Xiang, D.-R.; Sheng, J.-F. The analyse of effectiveness in HBeAg-positive chronic viral hepatitis B treated by adefovir dipivoxil combined with bicyclol. Zhonghua shi yan he lin chuang bing du xue za zhi = Zhonghua shiyan he linchuang bingduxue zazhi = Chin. J. Exp. Clin. Virol. 2009, 23, 299-301.

160. Laustsen, A.H.; Dorrestijn, N. Integrating Engineering, Manufacturing, and Regulatory Considerations in the Development of Novel Antivenoms. Toxins 2018, 10, 309. [CrossRef] [PubMed]

161. Williams, D.J.; Gutiérrez, J.-M.; Calvete, J.J.; Wüster, W.; Ratanabanangkoon, K.; Paiva, O.; Brown, N.I.; Casewell, N.R.; Harrison, R.A.; Rowley, P.D.; et al. Ending the drought: New strategies for improving the flow of affordable, effective antivenoms in Asia and Africa. J. Proteom. 2011, 74, 1735-1767. [CrossRef] [PubMed]

162. Gutiérrez, J.M.; Lomonte, B.; León, G.; Alape-Girón, A.; Flores-Díaz, M.; Sanz, L.; Angulo, Y.; Calvete, J.J. Snake venomics and antivenomics: Proteomic tools in the design and control of antivenoms for the treatment of snakebite envenoming. J. Proteom. 2009, 72, 165-182. [CrossRef] [PubMed]

163. Calvete, J.J.; Fasoli, E.; Sanz, L.; Boschetti, E.; Righetti, P.G. Exploring the Venom Proteome of the Western Diamondback Rattlesnake, Crotalus atrox, via Snake Venomics and Combinatorial Peptide Ligand Library Approaches. J. Proteome Res. 2009, 8, 3055-3067. [CrossRef] [PubMed]

164. Fasoli, E.; Sanz, L.; Wagstaff, S.; Harrison, R.A.; Righetti, P.G.; Calvete, J.J. Exploring the venom proteome of the African puff adder, Bitis arietans, using a combinatorial peptide ligand library approach at different $\mathrm{pHs}$. J. Proteom. 2010, 73, 932-942. [CrossRef] [PubMed]

165. Righetti, P.G.; Boschetti, E.; Zanella, A.; Fasoli, E.; Citterio, A. Plucking, pillaging and plundering proteomes with combinatorial peptide ligand libraries. J. Chromatogr. A 2010, 1217, 893-900. [CrossRef] [PubMed]

166. Arnold, C. Synthetic Biology Tackles Antivenom. Nature 2016, 532, 292. [CrossRef] 
167. O'Brien, J.; Lee, S.H.; Onogi, S.; Shea, K.J. Engineering the protein porona of a synthetic polymer nanoparticle for broad-Spectrum Sequestration and Neutralization of Venomous Biomacromolecules. J. Am. Chem. Soc. 2016, 138, 16604-16607. [CrossRef]

168. Waheed, H.; Moin, S.F.; Choudhary, M.I. Snake Venom: From Deadly Toxins to Life-saving Therapeutics. Curr. Med. Chem. 2017, 24, 1874-1891. [CrossRef] [PubMed]

169. Hashemzadeh, M.; Furukawa, M.; Goldsberry, S.; Movahed, M.R. Chemical structures and mode of action of intravenous glycoprotein IIb/IIIa receptor blockers: A review. Exp. Clin. Cardiol. 2008, 13, 192-197. [PubMed]

170. Ondetti, M.A.; Williams, N.J.; Sabo, E.; Pluscec, J.; Weaver, E.R.; Kocy, O. Angiotensin-converting enzyme inhibitors from the venom of Bothrops jararaca. Isolation, elucidation of structure, and synthesis. Biochemistry 1971, 10, 4033-4039. [CrossRef] [PubMed]

171. Kumar, V.A.; Wickremasinghe, N.C.; Shi, S.; Hartgerink, J.D. Nanofibrous snake venom hemostat. ACS Biomater. Sci. Eng. 2015, 1, 1300-1305. [CrossRef] [PubMed]

172. Chan, Y.S.; Cheung, R.C.F.; Xia, L.; Wong, J.H.; Ng, T.B. Snake venom toxins: Toxicity and medicinal applications. Appl. Microbiol. Biotechnol. 2016, 100, 6165-6181. [CrossRef] [PubMed]

(C) 2019 by the authors. Licensee MDPI, Basel, Switzerland. This article is an open access article distributed under the terms and conditions of the Creative Commons Attribution (CC BY) license (http://creativecommons.org/licenses/by/4.0/). 